\title{
Relationships between gamma-ray attenuation and soils in SW England
}

David Beamish

Beamish, D., 2015. Relationships between gamma-ray attenuation and soils in SW England. Geoderma, 259-260, 174-186.

doi:10.1016/j.geoderma.2015.05.018

Corresponding author: David Beamish (dbe@bgs.ac.uk)

British Geological Survey, Keyworth, Nottingham NG12 5GG, UK

Tel: +44(0) 1159363432

Fax: +44(0) 1159363437

Email: dbe@bgs.ac.uk

Keywords: Airborne; Gamma-ray; Radiometric; Soil; Bedrock; UK

- Gamma-ray attenuation across soils of SW England assessed

- Variations observed in addition to those controlled by soil texture and bedrock.

- Postulated control of soil density and moisture examined.

- Much supporting information appears ambiguous.

- $\quad$ The data assist with soil property mapping. 


\section{ABSTRACT}

Soil studies using radiometric data typically employ one or more of the main, naturally occurring radioelement estimates (Potassium, Thorium and Uranium) to undertake a variety of soil property assessments. This study concerns an attenuation assessment of high-resolution radiometric data obtained by a recent airborne geophysical survey in SW England. These data provide continuous measurements over a wide-range of region-specific soils and their parent bedrock materials. A prime motivation for this study is the observed complexity of the spatial variance in the radiometric signal level. Although such data may be jointly classified according to soil and bedrock type, variable attenuation levels in the signal levels remain to be explained. The data appear to carry information on soil properties additional to that of texture or other available soil descriptors. Existing gamma-ray theory indicates that the attenuation behaviour of radiometric data is jointly controlled by soil density and wetness in the upper $\sim 60 \mathrm{~cm}$ of the soil profile. Low density, highly organic soils (e.g. peat) produce readily identifiable and variable attenuation zones. All soil types are predicted to attenuate radiometric signal levels but at lower density-wetness sensitivities. The broad radiometric response level is, as expected, found to be controlled by bedrock. Clay mineral soils provide the most uniform response behaviour with respect to bedrock type. Peat soils display the lowest amplitude and most variable signal levels. The data from similar bedrock formations, even with the same lithological descriptor (e.g. argillaceous), can display distinctly different geostatistical behavior when the same soil type is considered. A variety of inferred attenuation zones are discussed in relation to supporting information on soil property and soil and land-use classifications. Spatial inconsistencies in existing database descriptors of organic rich zones are demonstrated and it is evident that the radiometric data can assist in resolving such ambiguities. The supporting control information has been found to be often ambiguous or unavailable at a scale appropriate to the fieldof-view of the airborne measurements. Within this wider context, it is suggested that an observational database, such as that supplied by the radiometric data, may assist in providing enhanced spatial assessments of the soils and soil properties encountered

\section{Introduction}

Geophysical gamma-ray spectroscopy, both ground-based and airborne, is increasingly being used for the digital mapping of soil properties. The subject has a considerable historical pedigree (Talibudeen, 1964; Hyvönen et al., 2005) in terms of early studies. Ground-based studies at the field 
scale, using soil-sampling to control interpretation, have defined relationships between the measured radioelements and soil properties such as clay content (Van der Klooster et al., 2011), soil pH (Dickson and Scott, 1967), SOC (Wong and Harper, 1999), plant available potassium (Wong and Harper, 1999; Dierke and Werban, 2013) and CEC (Rodrigues et al., 2015). More extensive airborne data sets may also be used in soil property assessments (Cook et al., 1996) although control information is inevitably more sparse. The airborne data are also distinct in having a much larger field-of-view (i.e. a lower spatial resolution) but are invariably more extensive and data may be obtained continuously and uniformly over most terranes. The existing soil studies using radiometric data typically employ one or more of the main, naturally occurring radioelement estimates (Potassium, Thorium and Uranium), together with their ratios and Total Count (TC), to undertake soil assessments (Schwarzer and Adams, 1973; Cook et al., 1996; Taylor et al., 2002). More complex studies, in more arid environments, also deal with the relationship between the erosional characteristics of regolith and radiometric survey data (Wilford et al., 1997).

In contrast to the above, we here consider the behaviour of the attenuation of airborne radiometric data in relation to the soil properties that control this behaviour. The attenuation of radiometric signal due to water or soil moisture is well-established (Carroll, 1981; Grasty, 1997). Repeat (timelapse) airborne radiometric surveys have the capability to provide assessments of snow-water equivalent and/or soil moisture by estimation of the variation in attenuation, from a known calibrated baseline (Peck et al., 1971; Lougens, 1980). While studies of airborne data sets may note or discard unwanted attenuation features due to water or water-content, extensive studies of the radiometric signal attenuation levels in single baseline (meaning one-off) survey data sets are uncommon.

The present study considers a recent airborne radiometric data set from SW England with the purpose of assessing the attenuation characteristics of the data. It is acknowledged that one-off survey data do not provide an absolute reference for the degree of attenuation so only relative assessments (e.g. same soil and bedrock type) can be carried out. The primary purpose of the study is to evaluate the degree to which attenuation effects may be observed as a function of both soil and bedrock type. A prime motivation for the study is the observed complexity of the spatial variance in the radiometric signal levels. The data clearly carry soil information additional to that of texture or classification but without detailed study the behaviour remains unexplained. In order to carry out the assessment, a wide range of secondary information on soils, parent material, land-use and vegetation height is examined. The behaviours identified by the analysis should then inform other field-scale and airborne-scale studies of the type of attenuation effects that may be present in the data sets considered. 
As discussed later, the physical properties that control attenuation in soils are the bulk density and moisture content however such parameters are not routinely available at the appropriate scale and extent of an airborne survey. The two controlling factors are distinct from the soil properties typically examined at the field-scale although bulk density and soil texture are related (Saxton and Rawls, 2006).

The airborne radiometric data (TellusSW) obtained across SW England are shown in Figure 1. The full survey is extensive $\left(10,929 \mathrm{~km}^{2}\right)$ and the study presented is focussed on a main area of $29 \times 20 \mathrm{~km}$. Three additional subareas are then examined in detail. The main area partially contains one of the main outcropping, highly radiogenic granites that occur across the region. A series of Devonian and Carboniferous argillaceous sediments form the main bedrock units. These are interspersed with a series of lava and dolerite (microgabbro) intrusions. Mineral (clay) soils across the area are limited in extent with the main soil type being loam. Loam soils generally contain more moisture and humus than sandy soils and have better drainage and infiltration of water and air than silty soils.

A joint classification of the radiometric data by soil and bedrock type is undertaken. A GIS-based geostatistical assessment reveals the behavior of different bedrock types with respect to soil type. The assessment of low count (attenuation) behaviour of the distributions obtained is however difficult. This is due to the fact that the 'attenuation level' for any single or joint classification is arbitrary (there is no absolute baseline reference) and the fact that the classified distributions typically display non-parametric behaviour. Additionally, studies using low count inevitably employ data values that may approach the noise level of the data.

The TC data along with combined radioelement concentrations (Ternary images) are presented and discussed across the whole survey and within the selected subareas. It is evident that at the larger scale primary radiometric control is provided by bedrock units that may require assessment by their lithological or lithostratigraphic characteristics. At the more detailed scale, a series of attenuation zones, within the framework of primary bedrock control can be identified. The zones identified are then assessed using the extensive supporting information on soils and parent materials together with other land and landform characteristics.

\section{Theory}

It is assumed that bedrock material acts as a radionuclide parent to any derived (overlying) superficial (i.e. unconsolidated) sediments and soils. The bedrock is therefore considered to provide 
the primary radiometric response. The soil material, where present, attenuates the observed in-air gamma-ray flux primarily through density when the material is dry (Løvborg, 1984). Additional secondary attenuation effects are introduced when the material contains free or absorbed water (Grasty, 1977). The standard dry-material attenuation (an exponential decay) within the material is increased by the addition of water. The subsurface attenuation scale length (e.g. the depth across which $90 \%$ of the flux is attenuated) therefore depends on density and water content. The attenuation scale lengths may typically vary between $20 \mathrm{~cm}$ (highly intact bedrock) to $60 \mathrm{~cm}$ (wet peat) as discussed by Beamish, 2013). For the majority of moist soils we anticipate a scale length of between 40 and $60 \mathrm{~cm}$ (Beamish, 2013). It therefore follows that an investigation of attenuation behaviour of radiometric data could provide assessments of soil properties in the upper $60 \mathrm{~cm}$ of the soil profile.

In the absence of moisture, soil, superficial and bedrock materials will have comparable attenuation coefficients at a given source concentration (Carroll, 1981; Løvborg, 1984). Under this condition, the percentage of the gamma ray signal (S) from a particular depth in centimetres (d) is given by:

$S(d)=(1-\exp (-0.046 * \rho * d)) * 100$

where $\rho$ is the dry bulk density of the material in $\mathrm{g} . \mathrm{cm}^{-3}$ (Taylor et al., 2002). The factor 0.046 is an assumed mass attenuation coefficient for the material and the energy considered. This expression indicates that about $90 \%$ of the radiometric signal comes from the top $30 \mathrm{~cm}$ of a soil when the average bulk density is $1.6 \mathrm{~g} . \mathrm{cm}^{-3}$. It is then often stated that moisture within the soil increases the attenuation and the attenuation increases by approximately $10 \%$ for each $10 \%$ volumetric increase in water content. The statement, which suggests a linear relationship, is repeated in many publications e.g. Grasty and Minty (1995), Cook et al. (1996) and IAEA (2003).

Soils are actually defined as a three-phase system comprising solid, water and air. As noted by Løvborg (1984) and Grasty (1997), any hydrogen supplied to the material as absorbed or free water (e.g. pore water) then generates an additional attenuation provided by the additional electron content. Following Løvborg (1984) and Grasty (1997), Beamish (2013) calculated and demonstrated the non-linear attenuation behaviour of soil materials described by dry bulk density, moisture content and porosity. A revised attenuation sensitivity (i.e. the modification of expression (1)) of various generic soil types to the degree of saturation was then evaluated. It was found that the greatest increases in attenuation occur in the case of low-density (e.g. organic-rich) soils.

Following the analysis of Beamish $(2013,2014)$, we note here the behaviour of the additional attenuation sensitivity of the soil material (assumed to be vertically uniform) in relation to that described by equation (1). Mineral soils typically display a range of dry densities in the range 1.1 to 
$1.6 \mathrm{~g} \cdot \mathrm{cm}^{-3}$. Organo-mineral soils have densities below this interval with a likely lower limiting value of $0.1 \mathrm{~g} . \mathrm{cm}^{-3}$ in the case of blanket bog peat (totally organic material). Mineral soils typically provide an additional significant attenuation (say $20 \%$ ) only at high moisture levels. The organo-mineral and organic soils (with densities less than, say, $1 \mathrm{~g} \cdot \mathrm{cm}^{-3}$ ) display an increasing additional attenuation sensitivity with decreasing density. In the limiting case of wet peat, attenuation levels increase by $>50 \%$ over their 'dry' equivalents.

\subsection{UK soils}

Two particular aspects of attenuation behaviour arise in the case of the UK (i.e. a temperate, midlatitude zone) and these are (a) the prevalence of a 'lower-bound' on soil moisture and (b) the prevalence of organo-mineral and organic soils. UK soil property information at the national scale is currently supplied by a soil observatory server (http://mapapps2.bgs.ac.uk/ukso/home.html) which contains both soil and soil-parent material information. The data used here are described in the next section and they include estimates of soil moisture and bulk density in the topsoil $(0-15 \mathrm{~cm})$ layer. The technical background to the estimation is given by Emmett et al. (2010). When restricted to the extent of the SW England survey considered here, $2091 \mathrm{~km}$ grid-cell estimates are obtained. The lower and upper bounds of the topsoil moisture estimates (across all soil and land-use types) are $21 \%$ and $42 \%$, respectively, for the 2007 dataset. The equivalent limiting values are 0.17 and 1.30 $\mathrm{g} . \mathrm{cm}^{-3}$ in the case of the bulk density values. These survey-wide values, although appropriate to only the topsoil layer, are much less than those commonly used in the airborne radiometric literature. It seems evident that in theoretical studies of radiometric soil attenuation in the UK, a lower bound of say $20 \%$ moisture content may be considered appropriate. UK soils are characterized by the presence of a wide range of organo-mineral and loam-type soils. In these soils, typically defined as having $>10 \%$ carbon content, carbon content increases to form other general classifications of organic soil types with 'peat' generally defined as having $>50 \%$ organic content. The significance of the theoretical attenuation behavior is that the non-mineral soils will have variable attenuation characteristics that are a function of density (and moisture content) as carbon content changes with soil-type. Precise estimates of soil carbon content do not generally exist.

\section{Materials and methods}

\subsection{The airborne survey data}


The majority of the TellusSW survey (see Fig. 1) was flown in the latter half of 2013. The 61,000 line$\mathrm{km}$ of data (Beamish et al., 2014) and the processing undertaken are described by Beamish and White (2014). The survey used a N-S line separation of $200 \mathrm{~m}$ and a radiometric data sampling of 1 $\mathrm{Hz}$ providing a mean along-line sampling of $71 \mathrm{~m}$. The survey achieved a mean flying elevation of 92 $\mathrm{m}$ from a nominal elevation of $80 \mathrm{~m}$. The radiometric data were acquired with a 256 channel gamma spectrometer system (e.g. GeoExploranium GR-820/3) comprising 32 litres of downward-looking $\mathrm{NaI}(\mathrm{TI})$ detectors and 8 litres of upward-looking detectors. Uranium $\left({ }^{238} \mathrm{U}\right)$ is estimated through the radon daughter ${ }^{214} \mathrm{Bi}$ in its decay chain, while Thorium $\left({ }^{232} \mathrm{Th}\right)$ is estimated through ${ }^{208} \mathrm{Tl}$ in its decay chain. Potassium $\left({ }^{40} \mathrm{~K}\right)$ is measured directly at $1.461 \mathrm{MeV}$. Conventionally secular equilibrium in the decay chains of ${ }^{238} \mathrm{U}$ and ${ }^{232} \mathrm{Th}$ (Minty, 1967) is assumed and the ground concentration results are reported as equivalent Uranium (eU, ppm) and equivalent Thorium (eTh, ppm). Potassium is reported as \%K. A vertically uniform activity concentration is assumed. The standard energy windows used are shown in Table 1.

Table 1. Spectral energy ranges of the airborne radiometric data.

\begin{tabular}{|l|l|l|}
\hline Window & Nuclide & Energy range (MeV) \\
\hline Thorium (eTh) & ${ }^{208} \mathrm{Tl}(2.61 \mathrm{MeV})$ & $2.41-2.81$ \\
\hline Uranium (eU) & ${ }^{214} \mathrm{Bi}(1.76 \mathrm{MeV})$ & $1.65-1.86$ \\
\hline Potassium (\%K) & ${ }^{40} \mathrm{~K}(1.46 \mathrm{MeV})$ & $1.37-1.57$ \\
\hline Total Count (cps) & - & $0.40-2.81$ \\
\hline
\end{tabular}

The radiometric processing used well-established guidelines and procedures developed by IAEA $(1991,2003,2010)$. The gamma radiation registered by the detector is composed of contributions from soil/rock, the atmosphere, the aircraft and cosmic radiation. In order to calibrate airborne radiometric data, the commonly adopted standard is to follow the recommendations made in a series of technical documents and publications from the International Atomic Energy Agency (IAEA). The set of procedures applied here are based on protocols described in IAEA (1991) and by Grasty and Minty (1995).

The individual radionuclides and their ratios offer the most appropriate means of classifying materials. When studying attenuation, the Total Count (TC) data, covering a wider spectral range, offer a higher signal/noise ratio than the individual components. When studying attenuation, and 
examining the low count behaviour of the data, the signal/noise ratio is clearly important. The 'zerolevel' characteristics of the processed radiometric data were obtained from survey data over deep sea water. The analysis, using over 40,000 data points, indicates a standard deviation of the zero level TC data of 73 cps.

The field of view of the airborne system is a significant factor in terms of the resolution of material property boundaries. The field of view depends on survey altitude, and is also a complex spatial function, peaking below the airborne receiver when the flux source can be considered an isolated body. The ground area or footprint, which contributes radioactivity to each $1 \mathrm{~s}$ measurement, was assessed by Pitkin and Duval (1980). For a stationary measurement, at a height of $60 \mathrm{~m}, 90 \%$ of the airborne response will be provided across a circle of radius 160 to $180 \mathrm{~m}$ (Kock and Samuelsson, 2011). In practice, with an along-line sampling of $70 \mathrm{~m}$, and for a line-spacing of $200 \mathrm{~m}$, a grid cell interpolation of $50 \mathrm{~m}$ to $100 \mathrm{~m}$ is considered acceptable.

\subsection{Lidar elevation data}

Lidar data were acquired (as a separate survey) over the whole of the study area during the course of the geophysical survey (Ferraccioli et al., 2014). The data sets are provided at a spatial resolution of $1 \mathrm{~m}$ with an average height accuracy of $25 \mathrm{~cm}$. The potential of attenuation effects due to vegetation has been discussed by Ahl and Bieber (2010) in relation to forest/biomass cover. In the UK, both deciduous and conifer forest zones tend to be highly managed and typically form discrete polygons within the landscape. Land classification information on these zones is further described below.

\subsection{Land-use Classification}

The product used here is the UK Land Cover Map (LCM2007) produced by the Countryside Survey (Countryside Survey, 2007; Morton et al., 2011). The product is a parcel-based classification of land cover and it uses 23 classifications to map the UK at a cell resolution of $25 \mathrm{~m}$. LCM2007 class numbers used here include 1 (Broadleaf woodland), 2 (Coniferous woodland), 12 (Bog) and 15 (Heather).

\subsection{Soils and parent material}

The soil-parent material database used here is that developed for the UK by Lawley (2009). The generalised spatial resolution is approximately 1:50k. In overview, the survey area largely comprises lithoskeletal soils directly over bedrock ( $88.5 \%$ of total area), soils over superficial deposits account for only $11.5 \%$, with the majority of this accounted for by 'surficial' materials (superficial units that 
have a thin, blanket-like morphology or veneer). Within the $29 \times 20 \mathrm{~km}$ area there are 4 soil types with areas of $367 \mathrm{~km}^{2}$ (loam), $81 \mathrm{~km}^{2}$ (peat-loam), $69 \mathrm{~km}^{2}$ (peat) and $63 \mathrm{~km}^{2}$ (clay). Peat-loam, as used here, is considered as a mix of peat (organic matter) and loam textured mineral soil.

Soil structural degradation in the SW is high with structural damage resulting in enhanced surfacewater runoff from fields that should naturally absorb winter rain. (Palmer and Smith, 2013).

A wide-range of other soil databases have also been examined. UK soil information at the national scale is currently supplied by a soil observatory server, noted previously. One of the more useful products used here is the simplified (27 soil unit) Soilscape database (Farewell et al., 2011, Cranfield, 2014) since it provides descriptions of drainage within the classification lexicon. Again using the UK soil information supplied by the soil observatory, we can obtain estimates of gravimetric (\%) soil moisture (Henrys et al. 2014) and soil density (Henrys et al., 2012) in the topsoil (0-15 cm). The national scale data are supplied as $1 \mathrm{~km}$ centroids.

\subsection{Superficial deposits}

In order to apply a consistent approach to the assessment of peat responses in the geophysical data, we here use the peat mapping provided by the BGS superficial geology data. The data used is the peat classification of superficial materials contained within the BGS DiGMAPGB50 database (McMillan and Powell, 1999; Smith, 2013). The 1:50k data have been generalised from 1:10k maps captured by field surveyors from 1883 onwards. According to the BGS scheme, a map unit is defined as peat if (i) it is an organic deposit (i.e. predominantly non-mineral), (ii) its margin can be readily identified at the landscape scale during the survey (typically by vegetation/soil/topographical change) and (iii) where the unit can be augured and shown to be $>1 \mathrm{~m}$ thick. The peat data are generally considered to reliably represent deep peat although discrepancies at the detailed scale inevitably exist. A further database used in this study relating to the priority habitat inventory for England contains a blanket bog classification (Natural England, 2012). This data set operates through an open government licence and is tied to a reference map database at a scale of 1:1250.

\subsection{Bedrock}

The analysis uses 2 scales of bedrock classification obtained from the BGS digital map products. The 1:250,000 (250k) scale bedrock geological map (Smith, 2011) is used initially at the regional scale. In more detailed assessments, the 1:50,000 (50k) scale bedrock geological map (Smith, 2013) is used. In both products, each polygon is identified by a two-part 'LEX_ROCK' (lithostratigraphic) code such as CL_LAVA (Carboniferous Limestone Supergroup, Lava). The first part, Lexicon code, refers to the name of the unit, as listed in the BGS Lexicon of Named Rock Units and accessible on the BGS 
website at http://www.bgs.ac.uk/lexicon/home.cfm. The second part, RCS code, refers to the composition or lithology of the unit.

When restricted to the survey area, the $250 \mathrm{k}$-scale geology provides 53 LEX-RCS and 22 RCS classifications while the 50k-scale geology provides 415 LEX-RCS and 98 RCS classifications. As in previous assessments of UK radiometric and geological associations (Beamish and White, 2011) we here use the simpler lithological RCS bedrock characterisation. The case study area, discussed later, comprises a $29 \times 20 \mathrm{~km}$ area. Within this area only 7 main bedrock lithological units are present.

Table 2 describes the formations and the radiometric sampling densities within each unit.

Table 2. The 7 litholigical bedrock units within the main study area of $29 \times 20 \mathrm{~km}$. Nsamp refers to the number of radiometric samples within each unit. DEV=Devonian, CARB=Carboniferous, INT=Intrusion. Siliciclastic rocks largely consist of silica or silicates. Argillaceous rocks are clay rich. Chert is a form of microcrystallite quartz (e.g. flint).

\begin{tabular}{|l|l|l|l|}
\hline RCS code & Description & Nsamp & Period \\
\hline AROC & SILICICLASTIC ARGILLACEOUS-ROCK & 3629 & DEV-CARB \\
\hline AROC + CHRT & SILICICLASTIC ARGILLACEOUS-ROCK and CHERT & 9935 & CARB \\
\hline AROC + SDST & $\begin{array}{l}\text { SILICICLASTIC ARGILLACEOUS-ROCK and SANDSTONE } \\
\text { (UNDIFFERENTIATED) }\end{array}$ & 16165 & DEV-CARB \\
\hline DOLR & DOLERITE (SYNONYMOUS WITH MICROGABBRO) & 694 & DEV-CARB \\
\hline GNR & GRANITIC-ROCK & 13041 & INT \\
\hline LAVA & LAVA (UNDIFFERENTIATED) & 1532 & DEV-CARB \\
\hline LAVA + TUF & LAVA (UNDIFFERENTIATED) and TUFF & 185 & DEV-CARB \\
\hline
\end{tabular}

\section{Results}

\subsection{Whole survey}

The whole-survey radiometric Ternary image is shown in Figure 1a and an equal-area colour plot of the Total Count data is shown in Figure 1b. The Ternary image is a 3-way colour stretch formed from the distributions of Potassium (red), Thorium (green) and Uranium (blue). Both images are cut-to- 
coast to remove the null responses over the offshore area of the complete survey. The area contains a series of five outcropping granites and these are outlined and identified in Figure 1. The granites intruded the existing country rock during the Variscan Orogeny (290 Ma) and the outcrops form part of a much deeper batholith.

At the regional scale, it can be seen that a major transition in the spectral response (colour) occurs across a geological boundary (double arrow in Fig. 1) separating Devonian rocks to the SW from Carboniferous formations to the NE. Three large zones due to a low bedrock response are evident and these are indicated in Fig $1 \mathrm{~b}$ with blue arrows. The Lizard Complex in the south consists of an overthrust ophiolite (ocean-floor) sequence of rocks and this is clearly defined in Figure 1a,b. A second zone in the north is due to a specific Devonian lithology referred to as the Hangman Grit formation. The sandstone formation has a deltaic origin and the response behaviour indicates that lithostratigraphic, in addition to lithological, bedrock attributes have to be considered in attenuation studies. The third low response zone is associated with a relatively large zone of Devonian basaltic lava and tuffs (including slates and pyroclastics). The radiometric low response tracks these units in considerable detail (1:50k). The rocks also occur intermittently across the case study area, discussed below.

Within the Bodmin and Dartmoor granites low responses are caused by significant areas of peat formed on the high ground (moors) above the granites. The largest area of attenuation is due to blanket bog covering the majority of the western portion of the Dartmoor granite (see Figure1). Low values can also be observed along many coastal areas and estuaries. The zones with the highest radiometric responses are associated with, and largely confined to, the outcropping granite zones. The $29 \times 20 \mathrm{~km}$ case study area covering the western margin of the Dartmoor granite is identified in Figure 1.

\subsection{Case Study Area}

Figure $2 \mathrm{a}$ shows the 1:250k bedrock distribution across the $29 \times 20 \mathrm{~km}$ study area along the western margin of the Dartmoor granite. The area in the north is dominated by a Carboniferous (C), argillaceous sandstone formation. To the south a complex sequence of units involving both Carboniferous and Devonian formations are interspersed with intrusive Carboniferous Lava (L) and some Dolomite (D) formations (arrowed). 
The Ternary radiometric image across the area is shown in Figure $2 b$, alongside the bedrock linework from Figure 2a. The highest values in all 3 radioelements are identified in white while the combined-lowest values tend to black. It is very evident that the highly radiogenic granite has an extensive attenuation zone (i.e. a largely black response) which masks the high bedrock values. This is formed by the presence of an extensive upland blanket bog as discussed below.

A modern water reservoir, producing a largely null response, is labelled R. Larger water bodies, such as this, are useful in defining the level of the null response corresponding to total saturation. The northern Carboniferous formation displays a strong Thorium response and subtle changes in the response reveal detailed changes in lithology. To the south, this same unit shows different characteristics and significant masking by attenuated (black) responses is evident. The Lava (L) units are associated with a strong Potassium response while the Upper Devonian and Lower Carboniferous $(C+D)$ unit displays an intermediate Potassium-Thorium response. While such features would form the basis for an evaluation of bedrock radiochemistry, it is evident that a considerable amount of attenuation exists at a wide-range of scales. These zones are not wholly a function of bedrock geology and therefore require an assessment using soil, and other, information.

Figure $3 \mathrm{a}$ quantifies the low Total count behaviour evident in the Ternary image of Figure $2 \mathrm{~b}$. The 1:250k bedrock lines are retained for reference. An arbitrary low value threshold of $800 \mathrm{cps}$ is used and is applied to all the soil-bedrock types. The value is chosen since it appears optimum for outlining the area of peat shown in Figure $2 \mathrm{~b}$. Figure $3 \mathrm{~b}$ shows a simple four-unit textural classification of the soil (Lawley, 2009). The major soil textural class across the area is loam. Higher levels of organic matter are represented by the peat-loam and peat soils. Clay-rich mineral soils are only found in the NW of the study area. The four-unit classification should also translate to an approximate soil density variation that would show decreasing densities for the 4 soil units of clay>loam>peat-loam>peat.

The low-count contours of Figure 3a are retained for reference and are shown by the blue polygons in Figure $3 \mathrm{~b}$. Using the arbitrary threshold value, attenuation zones, at a variety of scales, are observed in association with loam, peat-loam and peat soils. The area of peat shows a close association with the outline of the attenuation zone defined by $\mathrm{TC}<800 \mathrm{cps}$. In detail (e.g. Fig. 3a) large intra-peat variations in the TC response are observed across the area of peat. The lowest values ( $\mathrm{TC}<100 \mathrm{cps}$ ), approach the noise level of a null (zero) response and would constitute a fully water saturated soil. These observations are common to an extensive set of airborne radiometric measurements across a wide-range of peat types (lowland and upland) in the UK (Beamish, 2014). The intra-peat variations in attenuation have been interpreted as variations in moisture content, with the lowest amplitude zones corresponding to $100 \%$ saturation. Density variations in the upper 
peat profile may also contribute and cannot be ruled-out without ground calibrations performed at a scale appropriate to the airborne measurements.

Using the four-unit soil textural classification, the Total Count data have been further classified by bedrock-type. The 1:250k RCS bedrock classification provides the 7 bedrock units identified in Table 2. The statistical behaviour of the Total Count data categorised by soil-type and RCS bedrock is summarised in the box-whisker plot of Figure 4 . The bedrock units of LAVA and LAVA-TUF have been aggregated. Inevitably, due to inherent soil-parent material associations, the bedrock types associated with each soil type are limited (e.g. no clay soils in association with granitic bedrock). Conventionally the interquartile range of the data (the coloured box) and the median value of the distribution (the bar contained within the box) relate to distributions which are typically lognormally distributed. When, as here, a number of distributions are non-parametric, the interquartile range is better termed a central-moment of the distribution. The clay soils form a stable, high-value response set with all central moments exceeding $1000 \mathrm{cps}$. The Lava-Tuff distribution is obtained from only 5 samples. The more extensive loam soils appear more variable and a set of bedrockspecific responses can be identified, particularly in the case of Dolerite (DOLR) and Granite (GNR). In the peat-loam response set, the AROC distribution contains only 27 samples. The remainder of the response set demonstrate a reduction in central moments over their Loam counterparts. In the two peat distributions, the AROC-CHRT distribution contains only 8 samples, and the peat-GNR response clearly displays the lowest value behaviour across the complete data set. It is apparent that the Total Count data display both bedrock and soil specific variations that may be identified from geostatistical analyses of this type.

When examining attenuation behaviour, it is the low value behaviour of the distributions that is evaluated. Figure 5a shows the distributions obtained for the same soil (loam) over three argillaceous (AROC) bedrock types. The first bedrock type (AROC) and the second mixed bedrock unit (AROC+SDST) give rise to distinct central moments (the best-fitting normal distributions are shown for reference) and the behaviour of their low-value tails are also distinct. The third bedrock type (AROC+CHRT) has a broader distribution (approaching bimodal) and the low value tail is clearly distinct. Figure $5 \mathrm{~b}$ shows two different soils (peat-loam and peat) over highly radiogenic granitic bedrock. As has already been noted, the peat low-value behaviour is exceptional while the peatloam soils display a broad distribution encompassing both high and low values. From the soilbedrock analyses conducted it is apparent that no single low value attenuation threshold value can be routinely applied unless a soil-bedrock classification is fully explored. 
Due to relatively high spatial resolution of the data, the soil-bedrock assessment requires to be undertaken at a 1:50k scale or better. Two areas (A and B), shown in Figures 2 and 3, were selected for further more detailed attenuation analysis.

\subsubsection{Sub-area $A$}

This $9 \times 7 \mathrm{~km}$ sub-area contains loam, peat-loam and peat soils (Fig 3b). Here we are primarily interested in the attenuation zones observed to the west of the granite margin. Figure 6a shows a continuous colour image of the Total Count data restricted to the off-granite area. The lowest value circular feature is arrowed. Superimposed on this image as a black contour are the zones where the Total Count value is $<750 \mathrm{cps}$. The red contour line is the peat zone discussed previously (e.g. Fig. $3 b)$. Figure $6 \mathrm{~b}$ shows the $1: 250 \mathrm{k}$ bedrock mapping with the $750 \mathrm{cps}$ contour repeated in black. The DOLR zones (pink polygons) might be expected to show a persistent low Total Count response (see Fig. 4) no such behaviour is observed in this area, and the central low Total Count values persist across both DOLR and AROC+CHRT formations. Figure $6 \mathrm{c}$ shows the 4-unit soil classification together with the $750 \mathrm{cps}$ Total Count contour in black. The peat-loam soils in the NW show an association with an attenuation zone but this is only partially repeated in the peat-loam soils adjacent to the ongranite peat. A further mapping of 'peat' is also shown by the blue contours. The blue contours denote the BGS superficial mapping of deep-peat, discussed previously. These show a partial association with the soil-defined textural peat but also show extensions to the west, taking in textural peat-loam and loam soils.

Figure $6 \mathrm{~d}$ further illustrates some of the interpretation complexity that arises in the case of mapping organic-rich soils. The red contour in Figure $6 \mathrm{~d}$ is obtained from the Land Use Classification database (LCM2007) and uses the class number 12 (bog). The zone defined is partially consistent with the soil classification of peat. A further estimate of 'blanket bog' was also obtained from the Natural England (2012) database. Blanket bog, by definition, refers to a peat soil association. The blanket bog polygons (there are two) are shown with blue infill and a blue outline. The western spur shows an association with the BGS mapping of deep peat but an additional zone in the NW is defined that displays a clear overlap with an attenuation zone.

The vegetation across the area has also been assessed. The area is largely upland moor (see below) and most vegetation heights are therefore low. No associations between tree canopy and the attenuation zones are evident. Given the results presented in Figure 6, the off-granite attenuation zones appear to be related to near-surface (soil) influences rather than bedrock variations. It appears that, despite a consideration of a wide-range of soil information (not all shown here), there 
appears to be no simple correlation of the attenuation zones with established soil mapping parameters.

A significant area of low count behaviour is arrowed in Figure 6. The zone appears above a uniform bedrock type (Fig. 6b). It may be associated with a peat-loam soil (Fig. 6c), a zone of deep peat (blue contour, Fig. 6c) or partially with a blanket bog (Fig. 6d). Various components of the Land Use Classification database (LCM2007) have also been assessed. The lowest off-granite Total Count zone (arrowed in Fig. 6a) was found to be associated with the LCM2007 classification of heather (code 15). It should be noted that this example is an exception rather than the rule. In order to retain landform characteristics when assessing the data sets, visualisation using a DTM has been employed. Figure 7 shows a perspective view of a DTM ( $20 \mathrm{~m}$ cell resolution, looking north) with an overlay of high-resolution air photography. The image is centred on the low-value circular feature (arrowed) and the white contours denote Total Count values of $<650 \mathrm{cps}$ which approximately outline the feature. The E-W diameter of the feature is about $760 \mathrm{~m}$. The black line denotes the edge of the granite outcrop. The yellow polygons are the outlines of heather zones (there are 10 across the area shown) from the LCM2007 database. In the circular feature, attenuation and a heather classification coexist with a change in texture evident in the photography. It should be noted that this is the only example of this effect observed across the whole $29 \times 20 \mathrm{~km}$ study area. The zone has been discussed since it represents the largest off-granite attenuation level observed across the study area (see Fig. 3a).

\subsubsection{Sub-area B}

According to the soil classification of Figure $3 \mathrm{~b}$, this $8 \times 8 \mathrm{~km}$ sub-area contains only loam soils so the complexities introduced by peat-loam and peat/bog should be absent. Figure 8a shows a continuous colour image of the Total Count data. Superimposed on this image are white contours which define zones were the Total Count value is $<900 \mathrm{cps}$ (the contour interval used is $100 \mathrm{cps}$ ). The contours are used as a reference to the attenuation zones discussed here. Also shown on the image are black lines defining the 1:250k bedrock variations shown in Figure $8 \mathrm{~b}$. Figure $8 \mathrm{~b}$ shows the 1:250k bedrock mapping with the 900 cps TC contours repeated. Comparison of Figures $8 a$, b demonstrates the high value Total Count association with the AROC units in the north and south. In the south, a zone marked with an $\mathrm{X}$ indicates an area that appears to have an AROC affinity but is mapped as AROC+CHRT. Although the LAVA units (in red) do not have a distinctive Total Count response (Fig. 4), their strong potassium content is identified in the Ternary image of Figure 8c. The Ternary image has 
been 'colour-rescaled' to the $8 \times 8 \mathrm{~km}$ area. Due to the close association between a Total Count low (Fig. 8a) and a major zone of DOLR (labelled in Fig. 8b), Figure $8 \mathrm{c}$ also shows the 1:50k mapping of DOLR (referred to as microgabbro, MCGB, in the 1:50k lexicon) as white polygons. Some of the zones of MCGB are labelled ' $D$ ' in Figure $8 c$ to indicate some of the attenuation associations that exist. The general continuous behaviour of the attenuation across the northern portion of the area, and the spatial trends of the MCGB outcrop (Fig. 8c), suggest that the northern attenuation zone is linked to the presence of the MCGB formation. Further (revised) field mapping would be required to confirm this association.

In addition to the general soil classification of loam across the area, a wide-range of other soil databases has been examined. The Soilscape database (Cranfield, 2014) provides descriptions of drainage within the classification lexicon. Figure $8 \mathrm{~d}$ shows the Soilscape polygons defining 6 classifications across the area. Four of the units (2 to 5 ) are described as freely draining and one unit (1) is a floodplain soil. Unit 6 is defined as a slowly permeable, seasonally wet soil and this shows an evident association with the attenuation centre in the SW of the area ( $C$ in Fig. 8d). Interestingly, the attenuation zone also has a spur to the NE (labelled S in Fig 8d).

The SW area has a significant vegetation canopy and this was examined using the Lidar-based estimate of vegetation height. Vegetation height, using a $1 \mathrm{~m}$ cell size, is shown in Figure 9a along with the attenuation contours (in black) used in the previous assessments. Maximum vegetationcanopy heights exceed $40 \mathrm{~m}$ but the colour-scale maximum has been set at $25 \mathrm{~m}$. It is evident that both the soil classification 6 (Fig. 8d) and an attenuation centre ( $\mathrm{C}$ in Fig. 8d and Fig. 9a) are located in a zone of variable canopy and the spur to the NE (S in Fig. 8d and 9a) does not appear to be canopy related since the zone is isolated within a wider area of canopy. In summary, vegetation effects related to attenuation are not apparent across the test area. Additionally the Countryside Survey topsoil $(0-15 \mathrm{~cm})$ soil moisture data are available as $1 \mathrm{~km}$ centroids. These are shown in colour-coded grid form in Figure 9b. The 4 classifications indicate the data range from 21 to $56 \%$ moisture content with two of the high value (44-56\%) grid cells associated with the extended zone of attenuation, and the forested area. Comparisons of this sort, although interesting, remain enigmatic due to the widely different scales of the assessments.

\section{Discussion}

Inevitably there exist natural and intrinsic associations between bedrock and soil-type. Study subarea A considered loam, peat-loam and peat soils. As expected, the peat soils, developed across a highly radiogenic upland granite area, display a high variability in observed attenuation levels (see Fig 3a). The analysis conducted also suggests that detectable zones of attenuation exist in the 
defined peat-loam and loam soils. If the current mapping (1:250k and 1:50k scales) of the low response and intrusive dolerite/microgabbro bedrock units is correct, then the attenuation zones appear to be associated with soil-related effects. An examination of the spatial variations in existing databases of peat-bog-blanket bog definitions has indicated further potential associations of the attenuation zones with organic rich soils. Since the associations are only partial, it is suggested that the radiometric data, and their attenuation, have a role to play in defining soil properties and undertaking associated soil mapping.

Study sub-area B largely contains loam soil types. The northern section of the area contains a series of intrusive bedrock units. The Lava sequences produce an identifiable radiometric signature while the fragmented Dolerite unit produces identifiable attenuation zones. When the bedrock units produce spatially complex radiometric variations, such as these, the primary bedrock variations are likely to mask any soil-related effects. An additional and extensive attenuation zone that appears related to a mapping of seasonally wet soil is evident. The radiometric data also define a spur extension to this zone which again indicates their potential role in defining soil properties.

\subsection{Sub-area C}

Mineral clay soils only occur in the northern part of the wider survey area (Fig. 3a). The single attenuation threshold (e.g. $<800 \mathrm{cps}$, see Fig. 3), applied to the whole data set, does not reveal any attenuation zones associated with the clay soils. A more systematic examination of the statistical behaviour of the Total Count data categorised by soil-type and RCS bedrock (e.g. Fig. 4) enabled attenuation zones within the clay soils to be defined. The thresholding of the low-tail values within each category remains arbitrary, particularly due to differences in the statistical distributions found across different categories (e.g. Fig. 5). Figure 10a shows the extent of the low tail distribution (Total Count $<1050 \mathrm{cps}$ ) across a $2 \times 2 \mathrm{~km}$ area (see Fig. 3 ) of clay soils. The categorisation used is clay above a parent material defined as alluvium (or drift) above the AROC+SDST bedrock unit (see Table 2). The colour grid is formed from $100 \mathrm{~m}$ cell values of the N-S survey data defining the low value tail and the colour scale shows Total Count values $<1050 \mathrm{cps}$. The background image is a 1:25k scale topographic map showing forested zones and several small water bodies in the NE. The water bodies lie between the survey lines and only partial attenuation is observed. The main attenuation zone occurs in the centre of the image and is clearly associated with the forested zone. The LCM2007 database defines the forested zone as largely conifer with a few small polygons of deciduous woodland. Vegetation heights, obtained from the Lidar data, are shown in Figure 10b along with the 
attenuation zones. The main Soilscape unit across the area is a broad zone of slowly permeable seasonally wet acid loamy and clayey soils (unit 6), discussed previously. Unit 3 was previously described and unit 7 is defined as slightly acid loamy and clayey soils with impeded drainage. Unit 6 occurs extensively across the area but the attenuation zone discussed is the only (or main) apparent zone within this soil unit.

The Countryside Survey topsoil $(0-15 \mathrm{~cm})$ soil moisture data, available as $1 \mathrm{~km}$ centroids are shown in colour-coded grid form in Figure 10d. Only 2 grid cells with high values (44-56\%) occur in the northern area of the wider survey. Although they refer entirely to soil properties (in the upper soil profile) they clearly show an association with the attenuation zone and corresponding forested area, rather than the soil mapping shown in Figure 10c. It should be noted that the example discussed is an exception rather than the rule. Many, highly geometrical (i.e. managed) forested/woodland areas exist within the survey area and the example chosen is one of the few to display such a clear and extensive effect.

\section{Conclusions}

The study indicates that the primary radiometric response, across the area, is controlled by bedrock. The clay soils provide the most uniform response behavior with respect to bedrock type. Peat soils, as expected, display the lowest signal amplitudes and the most variable Total Count behaviour. Similar bedrock types (e.g. argillaceous, clay-rich rocks) can display distinctly different geostatistical behavior and central moments, when the same soil-type is considered.

In the first sub-area (A), peat soils could be accurately mapped and strong intra-peat variations were observed. The results are in accord with previous UK investigations of peat areas. The intra-peat variations in attenuation have been interpreted as variations in moisture content, with the lowest amplitude zones corresponding to $100 \%$ saturation. A high degree of spatial variability in the mapping/database descriptors of organic-rich peat/bog zones was demonstrated. It is suggested that an observational database, such as that supplied by the radiometric data, may assist in providing enhanced spatial assessments of such soils. In the second sub-area (B), a pervasive but fragmented zone of Dolerite intrusion was found to dominate the attenuation response. The attenuation data together with the full spectral (ternary) response information indicated a number of areas where the radiometric data might guide a revised mapping of the 1:50k bedrock. If the current bedrock mapping is largely accepted then an extensive zone of attenuation was found to be coincident with a specific soil group described as seasonally wet. The zone was also found to partially coincident with a UK-wide, but low spatial resolution, estimate of high soil moisture content (44- 
56\%). The attenuation data also identified an additional low signal spur which again suggests the radiometric data may assist in providing enhanced spatial assessments of such soils.

Attenuation effects associated with mineral clay soils were more difficult to identify due to the generally lower variance in their responses. Since the preceding analyses indicated a lack of any discernable vegetation/canopy attenuation effect across the study area, one such highly atypical example above a clay soil was investigated (sub-area C). A highly regular forest zone (largely coniferous) was found to be coincident with an attenuation zone. If an atypical tree biomass response is rejected then a soil-associated response is required. The soil type is continuous across the attenuation zone but the zone was found to be coincident with a UK-wide estimate of high soil moisture content (44-56\%). It should be noted this is a specific, rather than a general result of such a correlation.

It is evident that peat soil attenuation effects are highly detectable but the behaviour in non-peat soils is less discernible particularly when the primary bedrock responses change rapidly. The supporting control information has been found to be often ambiguous or unavailable at a scale appropriate to the field-of-view of the airborne measurements. Finally it is noted that the results of this study may be quite distinct from those in other regions of the UK and also highly distinct from those in non-temperate regions.

\section{Acknowledgements}

Thanks go to Jon Busby for an internal review and to two further referees for helpful suggestions. Topographic map data based upon Ordnance Survey data with the permission of the Controller of Her Majesty's Stationery Office, (C) Crown copyright. Contains British Geological Survey materials (C) NERC 2014. LCM2007 [Countryside Survey] C Database Right/Copyright NERC - Centre for Ecology \& Hydrology. Model estimates of topsoil properties [Countryside Survey] ( ) Database Right/Copyright NERC - Centre for Ecology \& Hydrology. All rights reserved. Blanket Bog priority habitat inventory for England (C) Natural England copyright. Contains Ordnance Survey data (C) Crown copyright and database right. Soilscapes data (C) Cranfield University and for the Controller of HMSO, 2011. This paper is published with the permission of the Executive Director, British Geological Survey (NERC). 


\section{References}

Ahl, A., Bieber, G., 2010. Correction of the attenuation effect of vegetation on airborne gamma-ray spectrometry data using laser altimeter data. Near Surface Geophysics 8, 271-278.

Beamish, D., White, J.C., 2011. A radiometric airborne geophysical survey of the Isle of Wight. Proceedings of the Geologists' Association 122, 787-799.

Beamish, D., 2013. Gamma ray attenuation in the soils of Northern Ireland, with special reference to peat. Journal of Environmental Radioactivity 115, 13-27.

Beamish, D., 2014. Peat mapping associations of airborne radiometric survey data. Remote Sensing 6, 521-539.

Beamish, D., White, J., 2014 TellusSW : airborne geophysical data and processing report. British Geological Survey Open Report OR/14/014.

Beamish, D., Howard, A., Ward, E.K., White, J., Young, M. E., 2014. Tellus South West airborne geophysical data. NERC-National Geoscience Data Centre. Doi: 10.5285/73848363-57c1-480aa64e-c732e15c4b37.

Carroll, T.R., 1981. Airborne soil moisture measurement using natural terrestrial gamma radiation. Soil Science 132, 358-366.

Cook, S. E., Corner, R.J., Groves, P.R. and Grealish, G.J., 1996. Use of airborne gamma-radiometric data for soil mapping. Australian Journal of Soil Research 34, 183-194.

Countryside Survey, 2007. Technical Report No. 9/07 NERC/Centre for Ecology \& Hydrology 192pp. (CEH Project Number: C03259).

Cranfield, 2014. The Soils Guide. Cranfield University, UK. Last accessed 16/03/2015.

Dickson, B.L. and Scott, K.M., 1997. Interpretation of aerial gamma-ray surveys - adding the geochemical factors. AGSO Journal of Australian Geology and Geophysics 17, 187-200.

Dierke, C. and Werben, U., 2013. Relationships between gamma-ray data and soil properties at an agricultural test site. Geoderma 199, 90-98.

Emmett, B.A., Reynolds, B., Chamberlain, P.M., Rowe, E., Spurgeon, D., Brittain, S.A., Frogbrook, Z., Hughes, S., Lawlor, A.J., Poskitt, J., Potter, E., Robinson, D.A., Scott, A., Wood, C., Woods, C., 2010. 
Countryside Survey: Soils Report from 2007. Technical Report No. 9/07 NERC/Centre for Ecology \& Hydrology 192pp. (CEH Project Number: C03259).

Farewell, T.S., Truckell, I.G., Keay, C.A., Hallett, S.H. 2011. The derivation and application of Soilscapes: soil and environmental datasets from the National Soil Resources Institute, Cranfield University.

Ferraccioli, F., Gerard, F., Robinson, C., Jordan, T., Biszczuk, M., Ireland, L., Beasley, M., Vidamour, A., Barker, A., Arnold, R., Dinn, M., Fox, A., Howard, A. 2014. LiDAR based Digital Surface Model (DSM) data for South West England. NERC-Environmental Information Data Centre doi:10.5285/b81071f2-85b3-4e31-8506-cabe899f989a.

Grasty, R.L., 1997. Radon emanation and soil moisture effects on airborne gamma ray measurements. Geophysics 62, 1379-1385.

Grasty, R.L., Minty, B.R.S., 1995. A guide to the technical specifications for airborne gamma-ray surveys. AGSO Australian Geological Survey Organisation, Record 1996/60.

Henrys, P.A., Keith, A.M., Robinson, D.A., Emmett, B.A. 2012. Model estimates of topsoil pH and bulk density [Countryside Survey]. NERC-Environmental Information Data Centre doi:10.5285/5dd624a9-55c9-4cc0-b366-d335991073c7.

Henrys, P.A., Keith, A.M., Robinson, D.A., Emmett, B.A. 2014. Model estimates of topsoil moisture [Countryside Survey]. NERC-Environmental Information Data Centre doi:10.5285/8db84900-5fdb43be-a607-e56c843d9b87.

Hyvönen, E., T., P., Vanhanen, E., Arkumaa, H., Sutinen, R., 2005. Airborne Gamma-ray Surveys in Finland: Geological Survey of Finland, Special Paper, 39, pp. 119-134.

IAEA, 1991. Airborne gamma ray spectrometer surveying. International Atomic Energy Agency, Vienna, Technical Report Series, No. 323.

IAEA, 2003. Guidelines for radioelement mapping using gamma ray spectrometry. International Atomic Energy Agency, Vienna, Technical Report Series, No. 136.

IAEA, 2010. Radioelement Mapping. International Atomic Energy Agency, Vienna, Nuclear Energy Series, No. NF-T-1.3.

Kock, P., Samuelsson, C., 2011. Comparison of airborne and terrestrial gamma spectrometry measurements - evaluation of three areas in southern Sweden. Journal of Environmental Radioactivity 102, 605-613. 
Lawley, R., 2009. The Soil parent material database: A User Guide. British Geological Survey Internal Report, OR/08/034.

Lougens, H.S. 1980. Determination of Soil Water Content from Terrestrial Gamma Radiation Measurements. Water Resources Research 16, 565-573.

Løvborg, L. 1984. The calibration of portable and airborne gamma-ray spectrometers - theory, problems and facilities. Risø Report M-2456. pp. 207.

McMillan, A.A., Powell, J.H. 1999. BGS Rock Classification Scheme Volume 4. Classification of artificial (man-made) ground and natural superficial deposits - applications to geological maps and datasets in the UK. British Geological Survey Research Report, RR 99-04.

Morton, D., Rowland, C., Wood, C. Meek, L., Marston, C., Smith, G., Wadsworth, R., Simpson, I.C., 2011. Final Report for LCM2007 - the new UK land cover map. Countryside Survey Technical Report No 11/07 NERC/Centre for Ecology \& Hydrology 112pp. (CEH Project Number: C03259).

Minty, B.R.S. 1967. Fundamentals of airborne gamma-ray spectrometry. AGSO Journal of Australian Geology and Geophysics 17, 39-50.

Natural England, 2012. Digital Boundary Data for Designated Wildlife Sites and related information, Version 2.7.

Palmer, R.C., Smith, R.P. 2013. Soil structural degradation in SW England and its impact on surfacewater runoff generation. Soil Use and Management 29, 567-575.

Peck, E.L., Bissel, V.C., Jones, E.B., Burge, D.L. 1971. Evaluation of snow-water equivalent by airborne measurements of passive terrestrial gamma radiation. Water Resources Research 7, 1151-1159.

Pitkin, J. A., Duval, J. S. 1980. Design parameters for aerial gamma ray surveys. Geophysics 45, $1427-$ 1439.

Rodrigues, Jr., F.A., Bramley, R.G.V., Gobbett, D.L., 2015. Proximal soil sensing for precision agriculture: simultaneous use of electromagnetic induction and gamma radiometrics in contrasting soils. Geoderma 243-244, 183-195.

Saxton. K.E., Rawls, W.J., 2006. Soil water characteristic estimates by texture and organic matter for hydrologic solutions. Soil Science Society of America Journal, 70, 1569-1578.

Schwarzer, T.F., Adams, J.A.S. 1973. Rock and Soil Discrimination by Low Altitude Airborne GammaRay Spectrometry in Payne County, Oklahoma. Economic Geology 68, 1297-1312.

Smith, A., 2011. Digital Geological Map of Great Britain, information notes, 2011. British Geological Survey Open Report, OR/10/050. 
Smith, A., 2013. User Guide for the BGS DiGMapGB-50 data (V7). British Geological Survey Open Report, OR/13/008.

Talibudeen, O., 1964. Natural radioactivity in soils. Soils and Fertilizers 27, 347-359.

Taylor, M.J., Smettem, K., Pracillio, G., Verboom, W. 2002. Relationships between soil properties and high-resolution radiometrics, central eastern Wheatbelt, Western Australia. Exploration Geophysics 33, 95-102.

Van Der Klooster, E., Van Egmond, F.M., Sonneveld, M.P.W., 2011. Mapping soil clay contents in Dutch marine districts using gamma-ray spectroscopy. European Journal of Soil Science 62, 743753.

Wong, M.T.F., Harper, R.J., 1999. Use of on-ground gamma-ray spectroscopy to measure plantavailable potassium and other topsoil attributes. Australian Journal of Soil Research 37, 267-277.

Wilford, J.R., Bierwirth P.N., Craig, M.A. 1997. Application of airbone gamma-ray spectrometry in soil/regolith mapping and applied geomorphology. AGSO Journal of Australian Geology and Geophysics 17, 201-216. 


\section{Figure Captions}

Figure 1. Radiometric survey data (cut to coast) obtained from the TellusSW survey of SW England. Insert shows survey location. Five outcropping Variscan granites are identified and outlined. The double-arrow denotes a transition from Devonian (in the SW) to Carboniferous rocks (in the NE). The central rectangle $(29 \times 20 \mathrm{~km})$ denotes the main case study area considered here. BNG refers to British National Grid. (a) The ternary colour image obtained using the 3 radioelement ground concentrations. (b) The Total Count values shown using a linear colour scale. Blue arrows denote locations noted in the text.

Figure 2. The $29 \times 20 \mathrm{~km}$ study area from the TellusSW airborne geophysical survey of SW England. Rectangles show 3 subareas discussed in the text. (a) 1:250k bedrock polygons with a simplified geological lexicon. One Carboniferous Dolerite intrusion is arrowed. (b) Ternary radiometric image with the 1:250k bedrock line-work superimposed. Black response $(R)$ is a water reservoir.

Figure 3. The $29 \times 20 \mathrm{~km}$ study area from the TellusSW airborne geophysical survey of SW England. Rectangles show 3 subareas (A, B and C) discussed in the text. (a) Contours of Total Count $<800 \mathrm{cps}$ with 1:250k bedrock line-work superimposed. $R$ is a water reservoir. $A$ low off-granite response is arrowed. (b) Colour polygons of a simple 4-unit soil classification with grey zones denoting Total Count $<800 \mathrm{cps}$ superimposed as a blue contour.

Figure 4. A box-whisker plot of soil-bedrock classified behaviour of Total Count across the $29 \times 20 \mathrm{~km}$ study area. The 4 soil units are inherently associated with different bedrock types. Poorly sampled distributions are noted in the text.

Figure 5. Normalised frequency distributions of soil-bedrock classified behaviour of Total Count across the $29 \times 20 \mathrm{~km}$ study area. (a) Loam soils for three similar argillaceous (ARC) bedrock types. (b) Peat-loam and peat soils above granite bedrock. The best-fitting normal distributions are also shown.

Figure 6. Study of Total Count attenuation across the $9 \times 7 \mathrm{~km}$ subarea A. (a) Continous colour image of Total Count restricted to the off-granite area. A significant area of low count behaviour is arrowed. Black contours enclose regions where Total Count $<750 \mathrm{cps}$. The black low value contours are repeated in the remaining images. The red contour line is the peat zone from Fig. 3b. (b) 1:250k bedrock polygons. (c) The 3 soil types (the dominant loam soil is in white, peat-loam in yellow, peat in brown) all with red boundaries. The blue contour is the superficial mapping of deep peat. (d) Two further mappings of peat-bog. Two blanket bog polygons are shown with blue infill and blue outline. The red contour is obtained from LCM2007 defined classification of bog. The black contour line is the peat zone from Fig. $3 b$.

Figure 7. 3D perspective view, looking north, across a DTM, of the arrowed low count feature in Fig. 6 , with an overlay of a high resolution air photograph. The main attenuation feature discussed is identified with a black arrow. The E-W extent of the feature is $760 \mathrm{~m}$. The white contours enclose areas with Total Count $<650 \mathrm{cps}$. The black line denotes the edge of the granite outcrop (granite to right of line). The yellow polygons are the outlines of heather zones from the LCM2007 database. 
Figure 8. Study of Total Count attenuation across the $8 \times 8 \mathrm{~km}$ subarea B. Location $(X)$ is discussed in the text. a) Continous colour image of Total Count. White contours enclose regions where Total Count < $900 \mathrm{cps}$, using a $100 \mathrm{cps}$ contour interval. Black lines represent outline 1:250k bedrock geology. (b) 1:250k bedrock geology with intrusive zones in red (LAVA) and and pink (DOLR). Black contours are repeated from Fig. 8a. (c) Ternary radiometric image with the 1:250k bedrock line-work superimposed. White polygons show DOLR (D) outlines at a scale of 1:50k. (d) Soilscape soil types. 1=Freely draining floodplain soils. 2=Freely draining acid loamy soils over rock. 3=Freely draining slightly acid but base-rich soils. 4=Loamy soils with naturally high groundwater. $5=$ Freely draining slightly acid loamy soils. $6=$ Slowly permeable seasonally wet acid loamy and clayey soils. Black contours are repeated from Fig. 8a. Locations identified by arrows ( $C$ and $S$ ) are discussed in the text.

Figure 9. Study of Total Count attenuation across the $8 \times 8 \mathrm{~km}$ subarea B. Black contours enclose regions where Total Count $<900 \mathrm{cps}$, using a $100 \mathrm{cps}$ contour interval (from Fig. 8a). (a) Lidar data (1 $m$ resolution) defining vegetation height. Locations identified by arrows ( $C$ and $S$ ) are discussed in the text. (b) Countryside survey topsoil $(0-15 \mathrm{~cm})$ soil moisture data $(1 \mathrm{~km}$ centroids) using 4 classifications.

Figure 10. Study of Total Count attenuation across the $2 \times 2 \mathrm{~km}$ subarea C. (a) Total count values below $1050 \mathrm{cps}$ with values < $1000 \mathrm{cps}$ in black. The image cells use line-based data, with a line separation of $200 \mathrm{~m}$. The image cells are repeated in the subsequent images. Background image is a 1:25k topographic map. (b) Lidar data (1 m resolution) defining vegetation height. (c) Soilscape soil types. 3=Freely draining slightly acid but base-rich soils. $6=$ Slowly permeable seasonally wet acid loamy and clayey soils. $7=$ slightly acid loamy and clayey soils with impeded drainage.(d) Countryside survey topsoil $(0-15 \mathrm{~cm})$ soil moisture data (1 km centroids) using 3 classifications. 
Figure 1. Radiometric survey data (cut to coast) obtained from the TellusSW survey of SW England. Insert shows survey location. Five outcropping Variscan granites are identified and outlined. The double-arrow denotes a transition from Devonian (in the SW) to Carboniferous rocks (in the NE). The central rectangle $(29 \times 20 \mathrm{~km})$ denotes the main case study area considered here. BNG refers to British National Grid. (a) The ternary colour image obtained using the 3 radioelement ground concentrations. (b) The Total Count values shown using a linear colour scale. Blue arrows denote locations noted in the text.
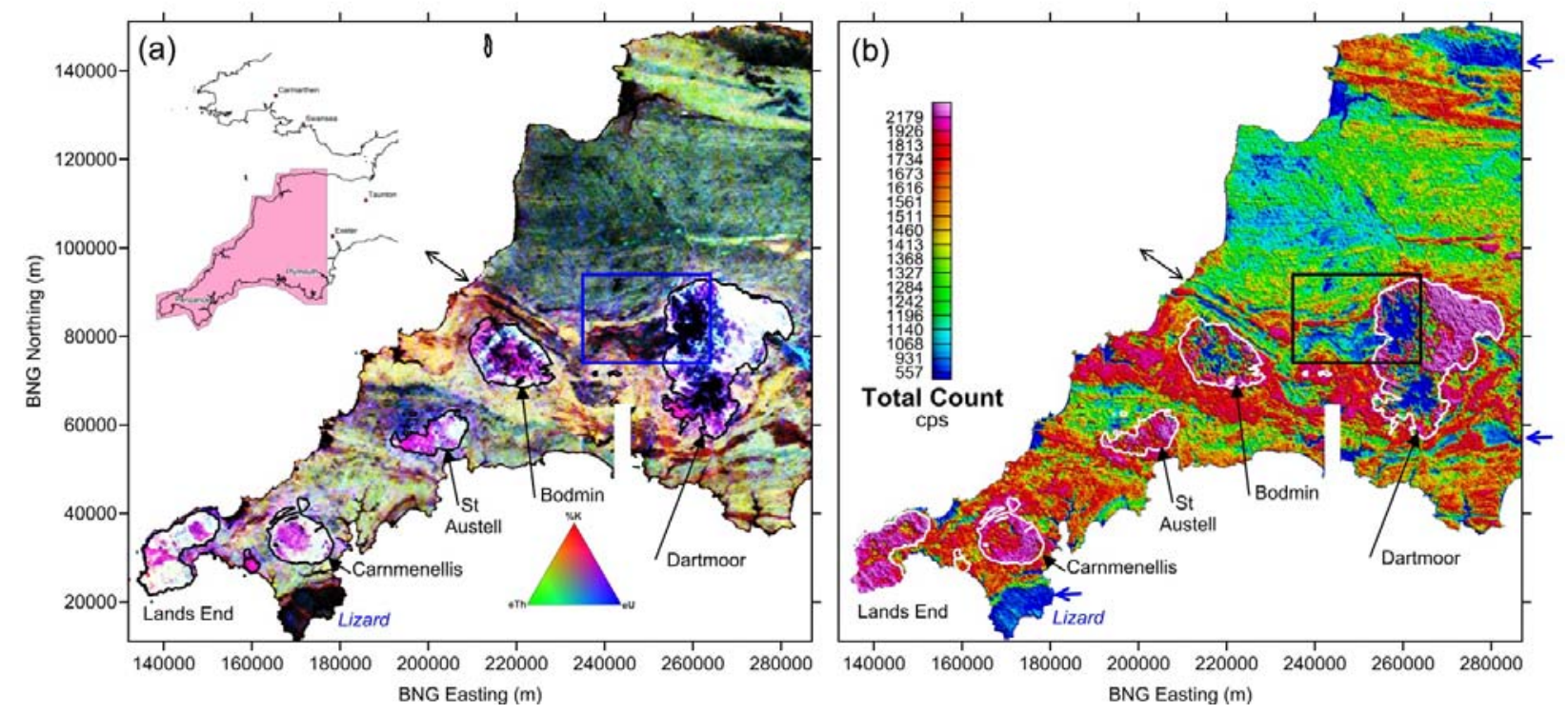
Figure 2. The $29 \times 20 \mathrm{~km}$ study area from the TellusSW airborne geophysical survey of SW England. Rectangles show 3 subareas discussed in the text. (a) 1:250k bedrock polygons with a simplified geological lexicon. One Carboniferous Dolerite intrusion is arrowed. (b) Ternary radiometric image with the 1:250k bedrock line-work superimposed. Black response $(R)$ is a water reservoir.
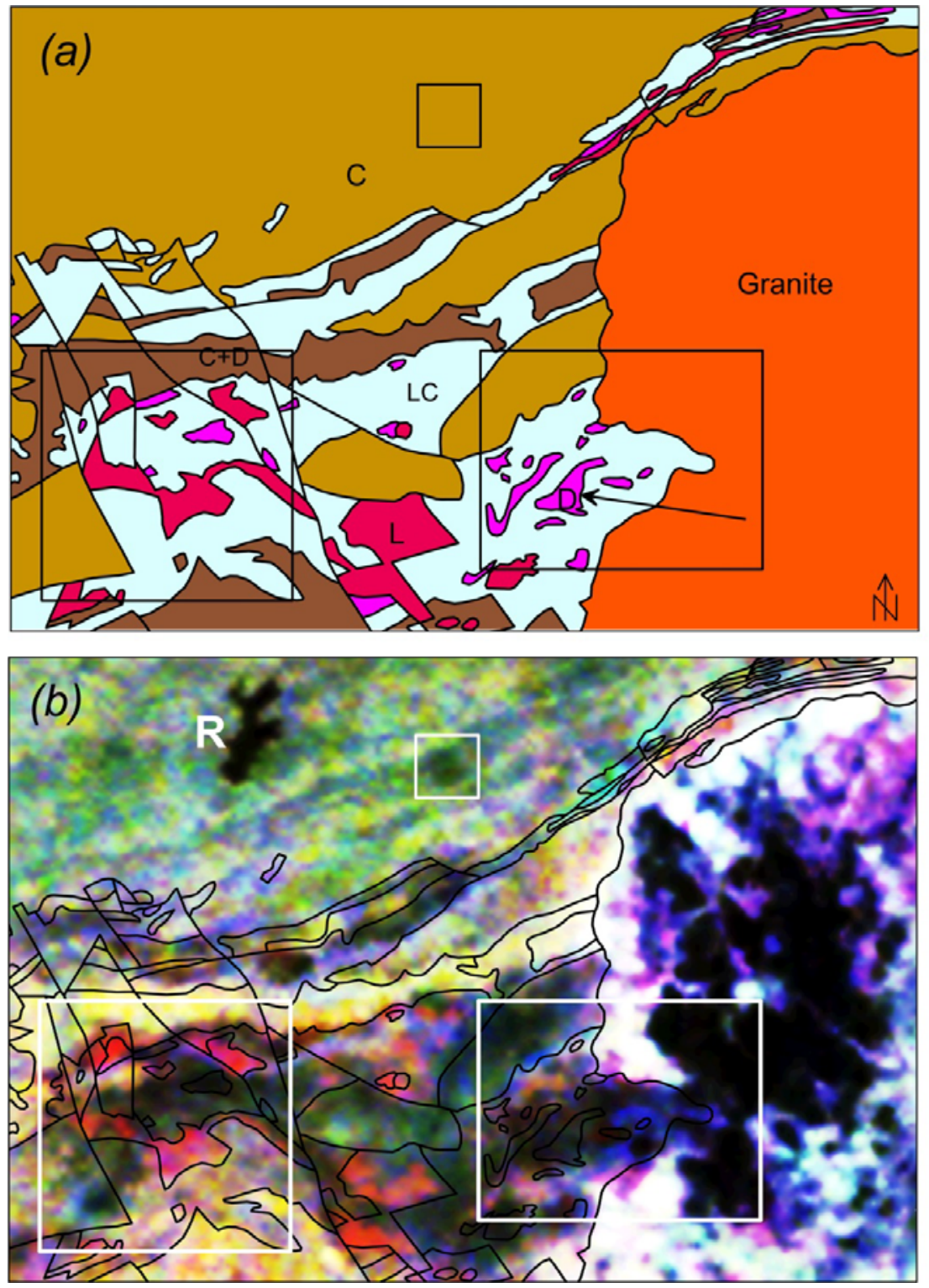

\section{C : Carboniferous}

Argillaceous rock and sandstone

LC : Lower Carboniferous

Argillaceous rock and chert

C+D : Upper Devonian and Lower Carboniferous Argillaceous rock

$\mathrm{L}$ : Carboniferous lava

D : Carboniferous Dolerite intrusion (arrowed)
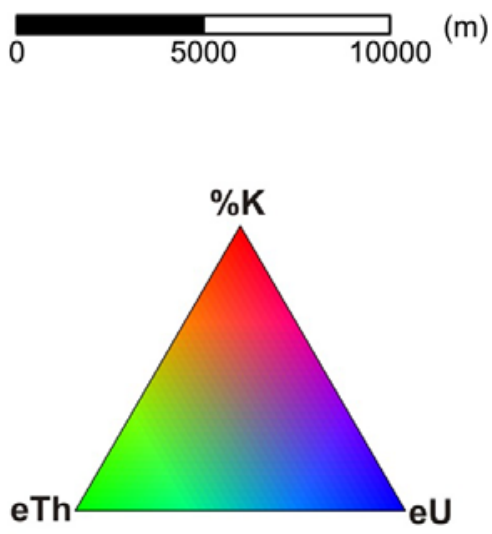
Figure 3. The $29 \times 20 \mathrm{~km}$ study area from the TellusSW airborne geophysical survey of SW England. Rectangles show 3 subareas (A, B and C) discussed in the text. (a) Contours of Total Count $<800 \mathrm{cps}$ with 1:250k bedrock line-work superimposed. $R$ is a water reservoir. A low off-granite response is arrowed. (b) Colour polygons of a simple 4-unit soil classification with grey zones denoting Total Count $<800$ cps superimposed.

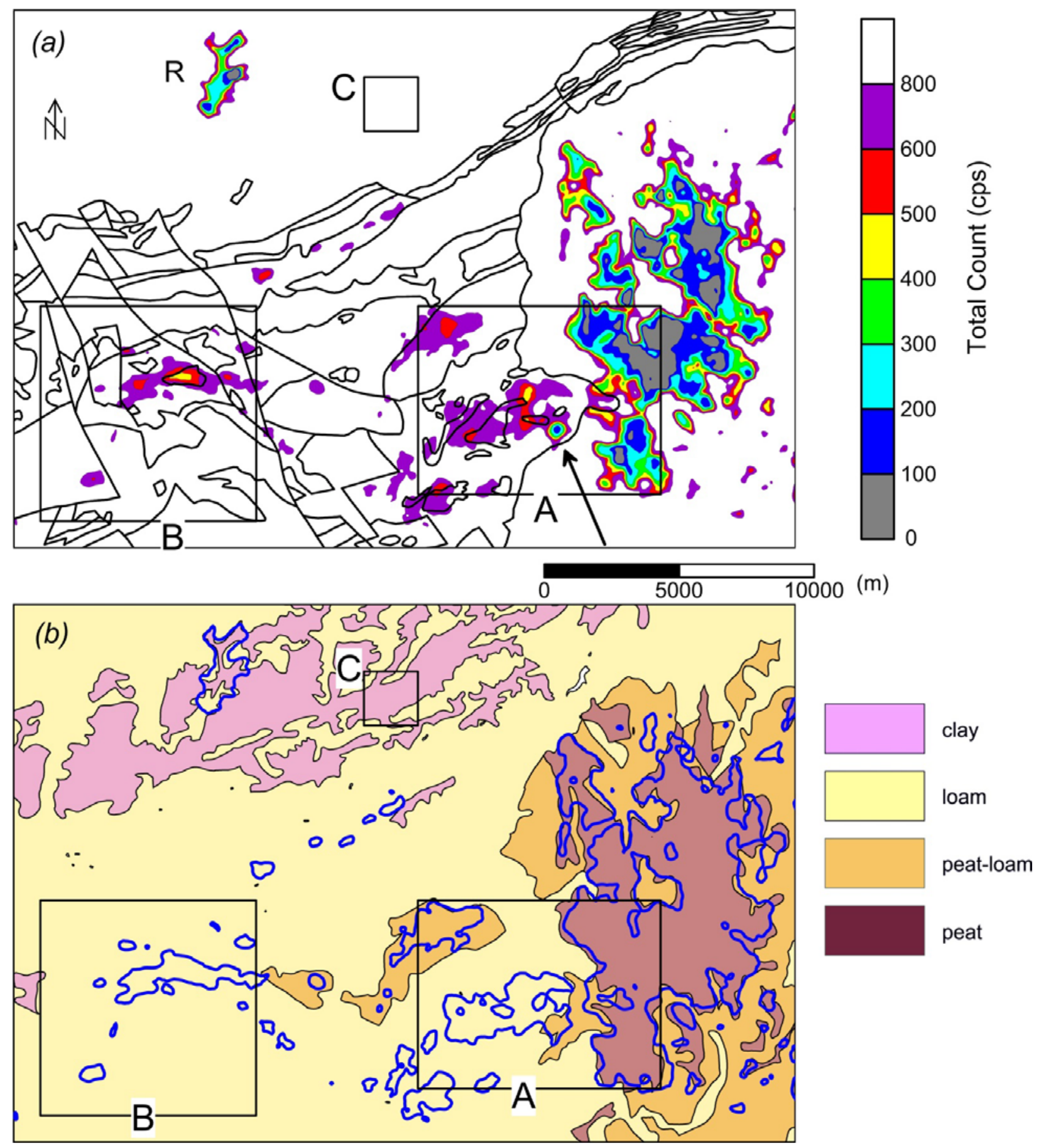


Figure 4. A box-whisker plot of soil-bedrock classified behaviour of Total Count across the $29 \times 20 \mathrm{~km}$ study area. The 4 soil units are inherently associated with different bedrock types. Poorly sampled distributions are noted in the text.

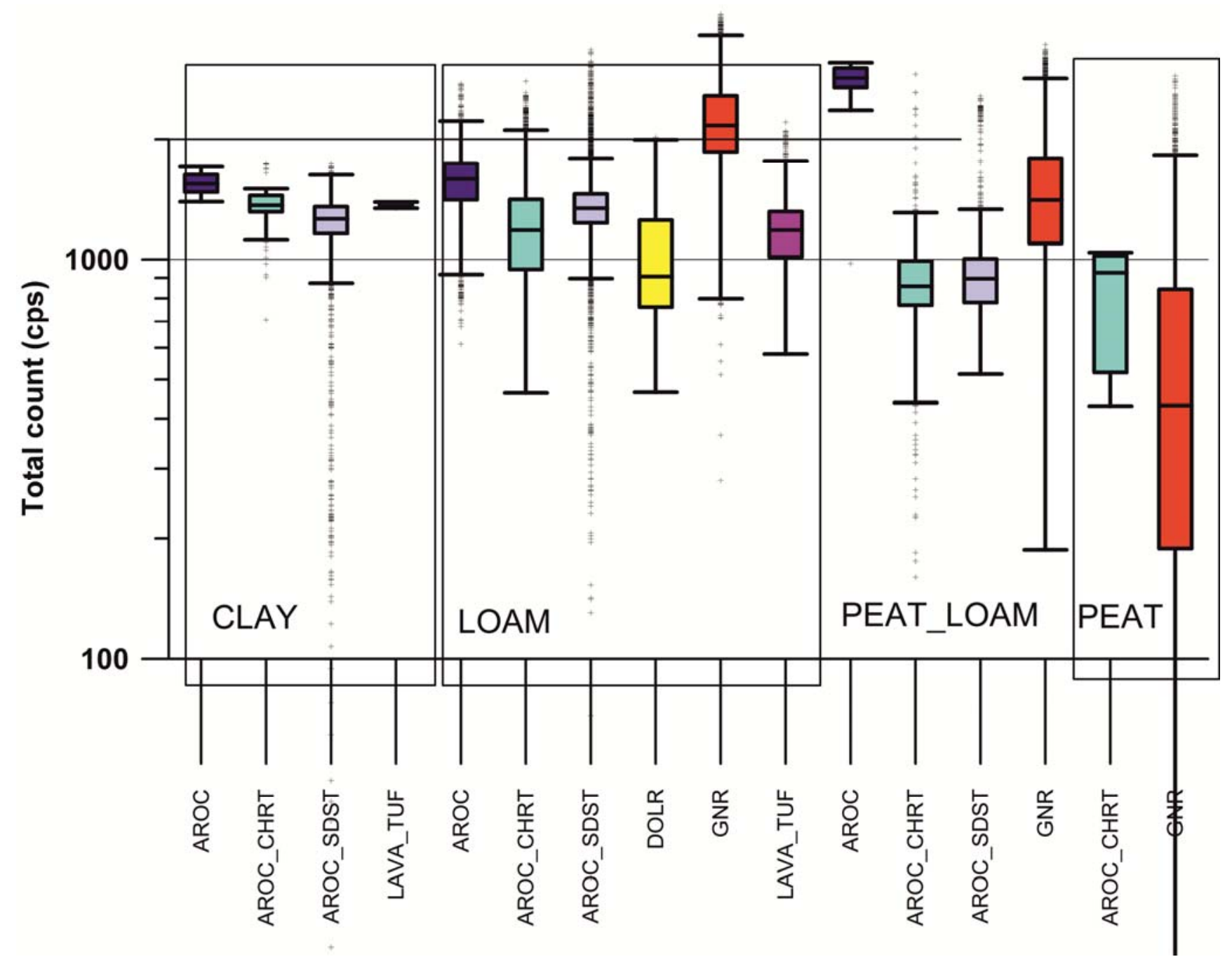


Figure 5. Normalised frequency distributions of soil-bedrock classified behaviour of Total Count across the $29 \times 20 \mathrm{~km}$ study area. (a) Loam soils for two similar bedrock types. (b) Peat-loam and peat soils above granite bedrock. The best-fitting normal distributions are also shown.
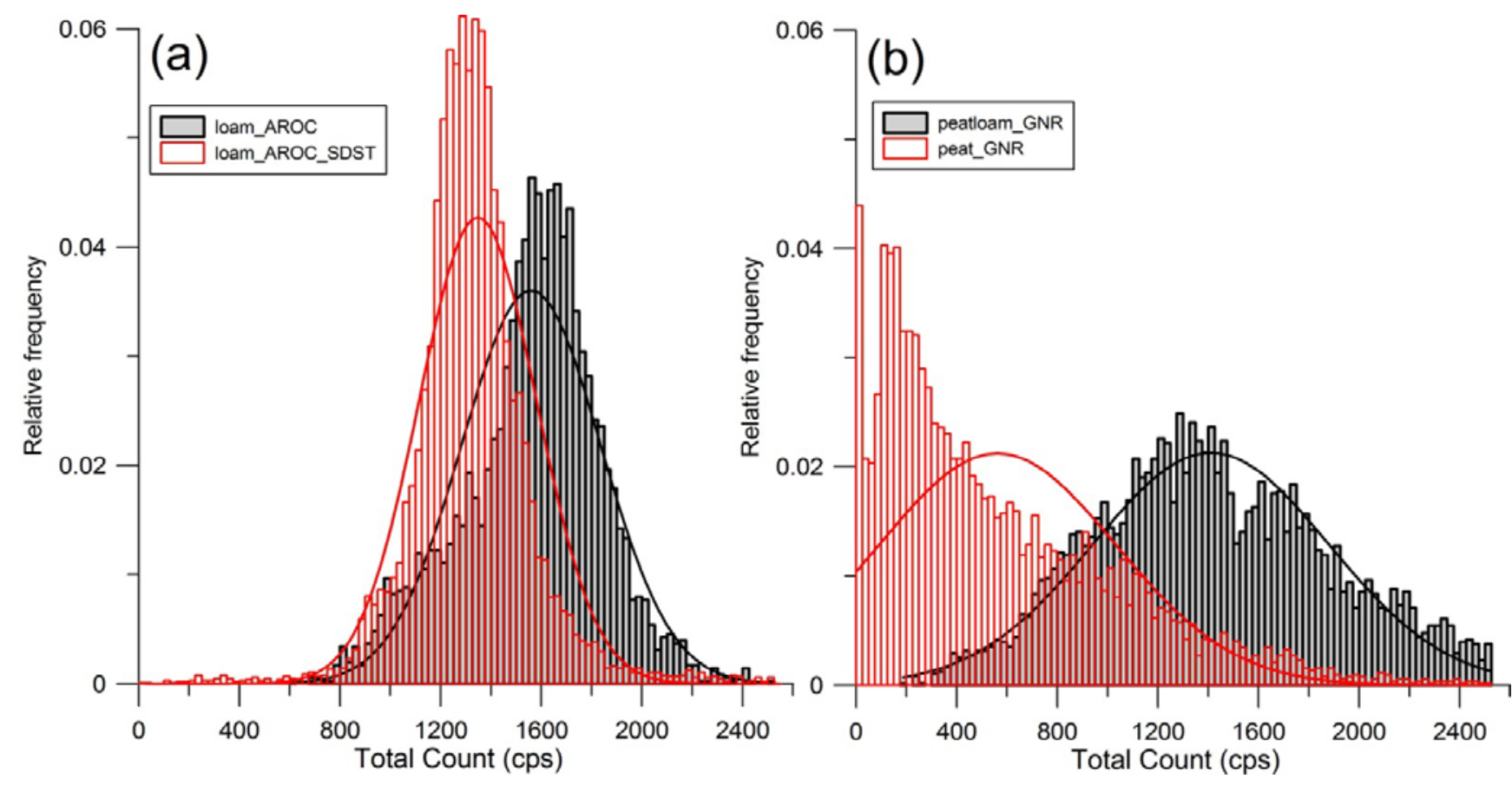
Figure 6. Study of Total Count attenuation across the $9 \times 7 \mathrm{~km}$ subarea A. (a) Continous colour image of Total Count restricted to the off-granite area. A significant area of low count behaviour is arrowed. Black contours enclose regions where Total Count $<750 \mathrm{cps}$. The black low value contours are repeated in the remaining images. The red contour line is the peat zone from Fig. 3b. (b) 1:250k bedrock polygons. (c) The 3 soil types (the dominant loam soil is in white, peat-loam in yellow, peat in brown) all with red boundaries. The blue contour is the superficial mapping of deep peat. (d) Two further mappings of peat-bog. Two blanket bog polygons are shown with blue infill and blue outline. The red contour is obtained from LCM2007 defined classification of bog. The black contour line is the peat zone from Fig. 3b.
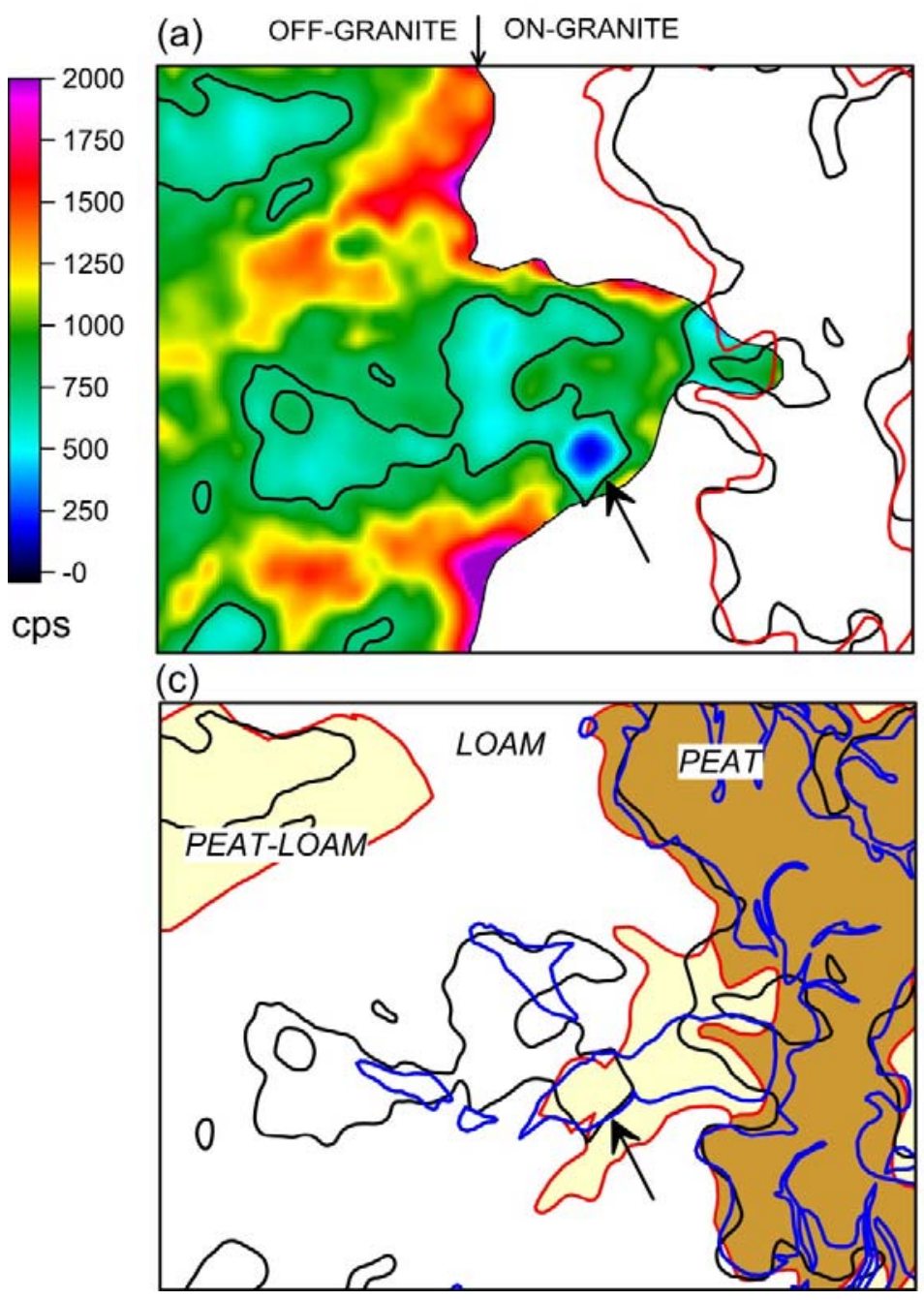

(b)

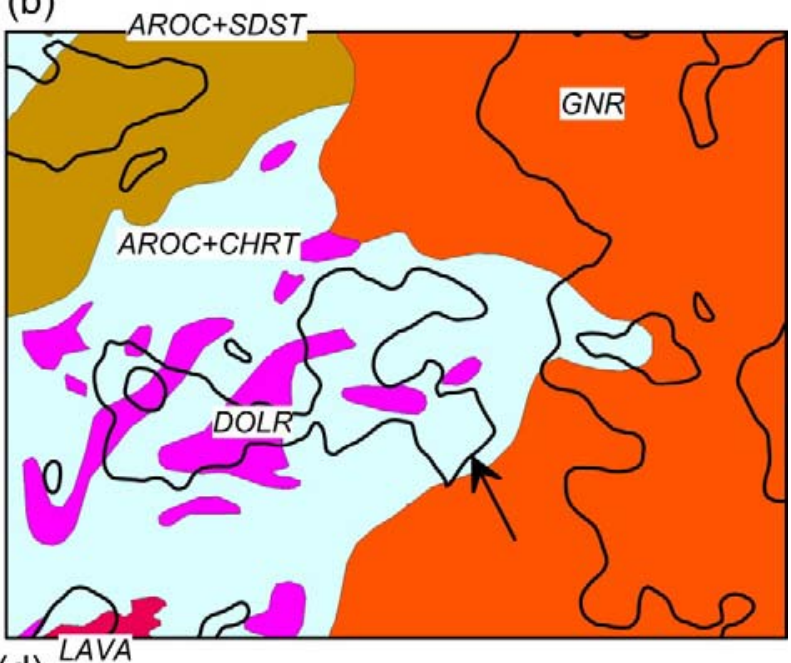

(d)

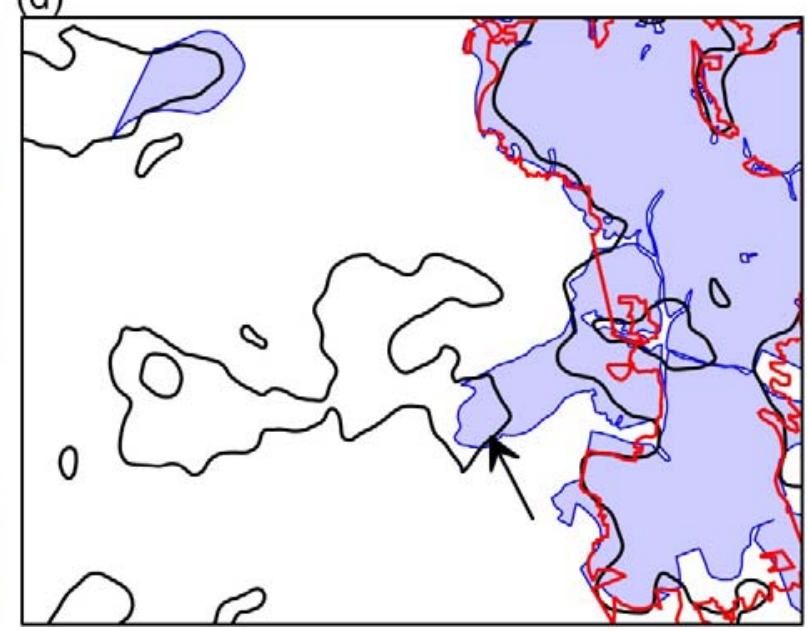


Figure 7. 3D perspective view, looking north, across a DTM, of the arrowed low count feature in Fig. 6 , with an overlay of a high resolution air photograph. The main attenuation feature discussed is identified with a black arrow. The E-W extent of the feature is $760 \mathrm{~m}$. The white contours enclose areas with Total Count $<650 \mathrm{cps}$. The black line denotes the edge of the granite outcrop (granite to right of line). The yellow polygons are the outlines of heather zones from the LCM2007 database.

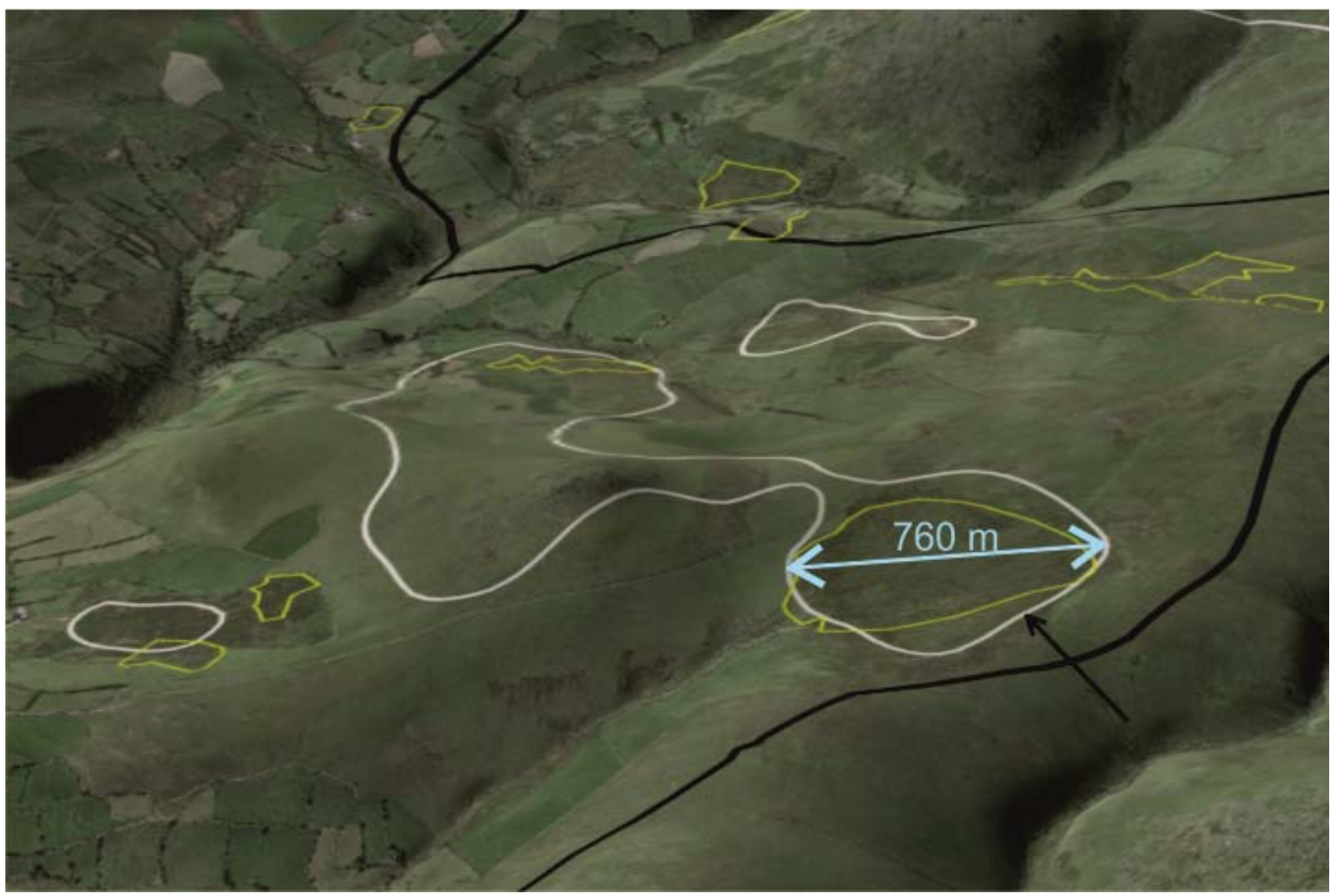


Figure 8. Study of Total Count attenuation across the $8 \times 8 \mathrm{~km}$ subarea B. Location $(X)$ is discussed in the text. a) Continous colour image of Total Count. White contours enclose regions where Total Count < $900 \mathrm{cps}$, using a $100 \mathrm{cps}$ contour interval. Black lines represent outline 1:250k bedrock geology. (b) 1:250k bedrock geology with intrusive zones in red (LAVA) and and pink (DOLR). Black contours are repeated from Fig. 8a. (c) Ternary radiometric image with the 1:250k bedrock line-work superimposed. White polygons show DOLR (D) outlines at a scale of 1:50k. (d) Soilscape soil types. 1=Freely draining floodplain soils. 2=Freely draining acid loamy soils over rock. 3=Freely draining slightly acid but base-rich soils. 4=Loamy soils with naturally high groundwater. $5=$ Freely draining slightly acid loamy soils. $6=$ Slowly permeable seasonally wet acid loamy and clayey soils. Black contours are repeated from Fig. 8a. Locations identified by arrows ( $C$ and $S$ ) are discussed in the text.

(a)

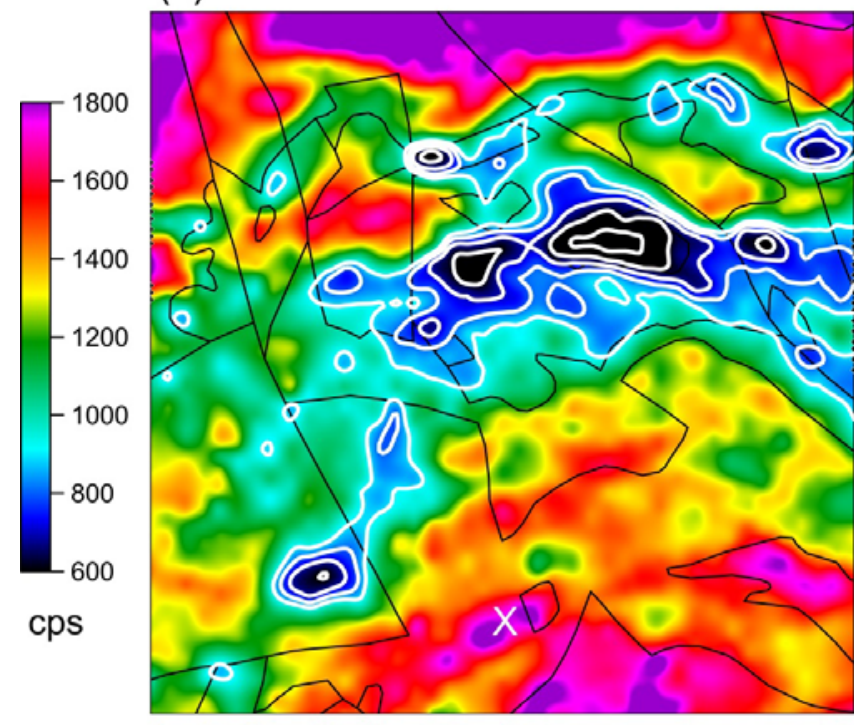

(c)

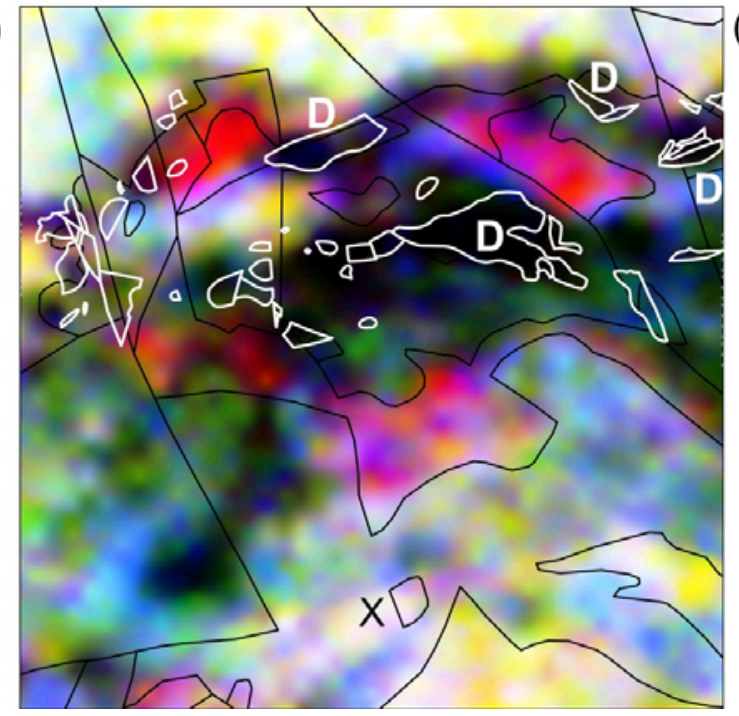

(b)

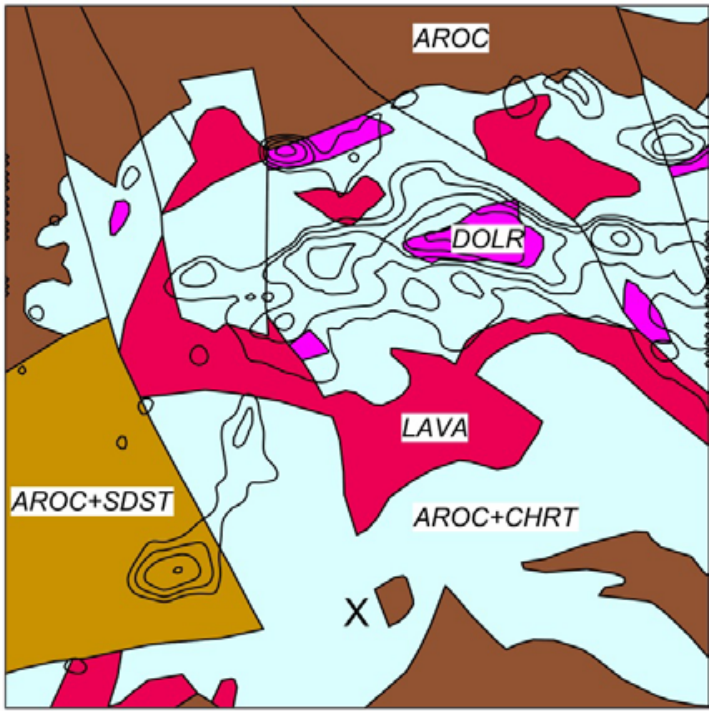

(d)

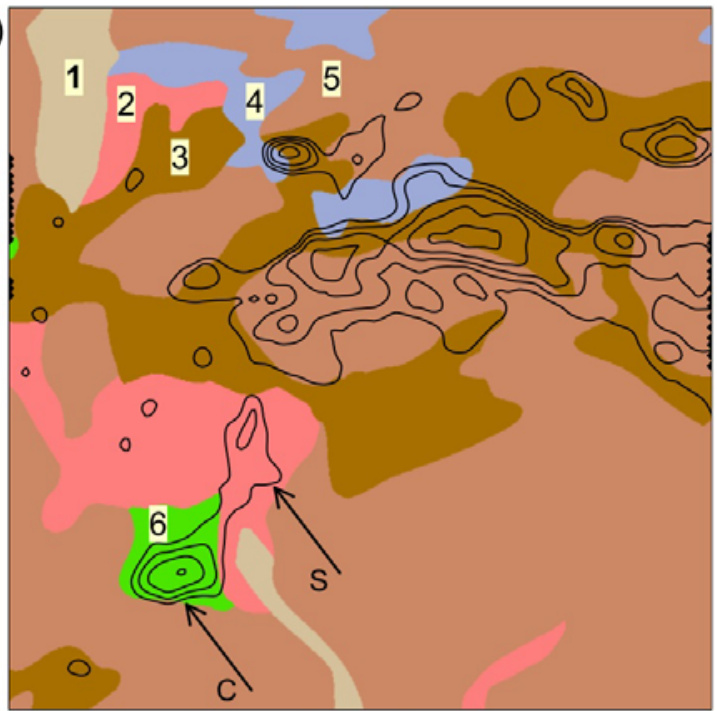


Figure 9. Study of Total Count attenuation across the $8 \times 8 \mathrm{~km}$ subarea B. Black contours enclose regions where Total Count < $900 \mathrm{cps}$, using a $100 \mathrm{cps}$ contour interval (from Fig. 8a). (a) Lidar data (1 $m$ resolution) defining vegetation height. Locations identified by arrows ( $C$ and $S$ ) are discussed in the text. (b) Countryside survey topsoil $(0-15 \mathrm{~cm})$ soil moisture data (1 $\mathrm{km}$ centroids) using 4 classifications.
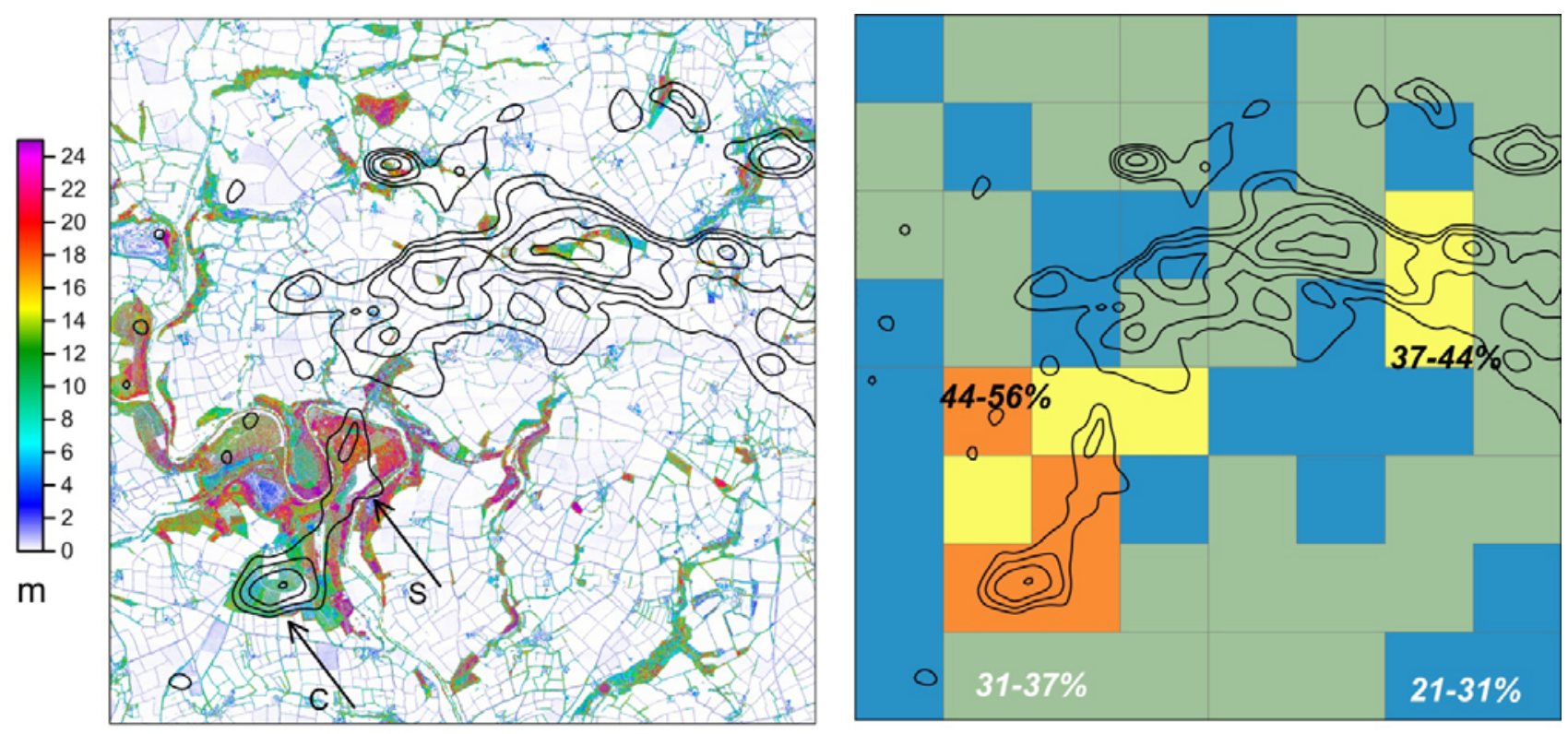
Figure 10. Study of Total Count attenuation across the $2 \times 2 \mathrm{~km}$ subarea C. (a) Total count values below $1050 \mathrm{cps}$ with values $<1000 \mathrm{cps}$ in black. The image cells use line-based data, with a line separation of $200 \mathrm{~m}$. The image cells are repeated in the subsequent images. Background image is a 1:25k topographic map. (b) Lidar data (1 $\mathrm{m}$ resolution) defining vegetation height. (c) Soilscape soil types. 3=Freely draining slightly acid but base-rich soils. $6=$ Slowly permeable seasonally wet acid loamy and clayey soils. 7=slightly acid loamy and clayey soils with impeded drainage.(d) Countryside survey topsoil $(0-15 \mathrm{~cm})$ soil moisture data $(1 \mathrm{~km}$ centroids) using 3 classifications.
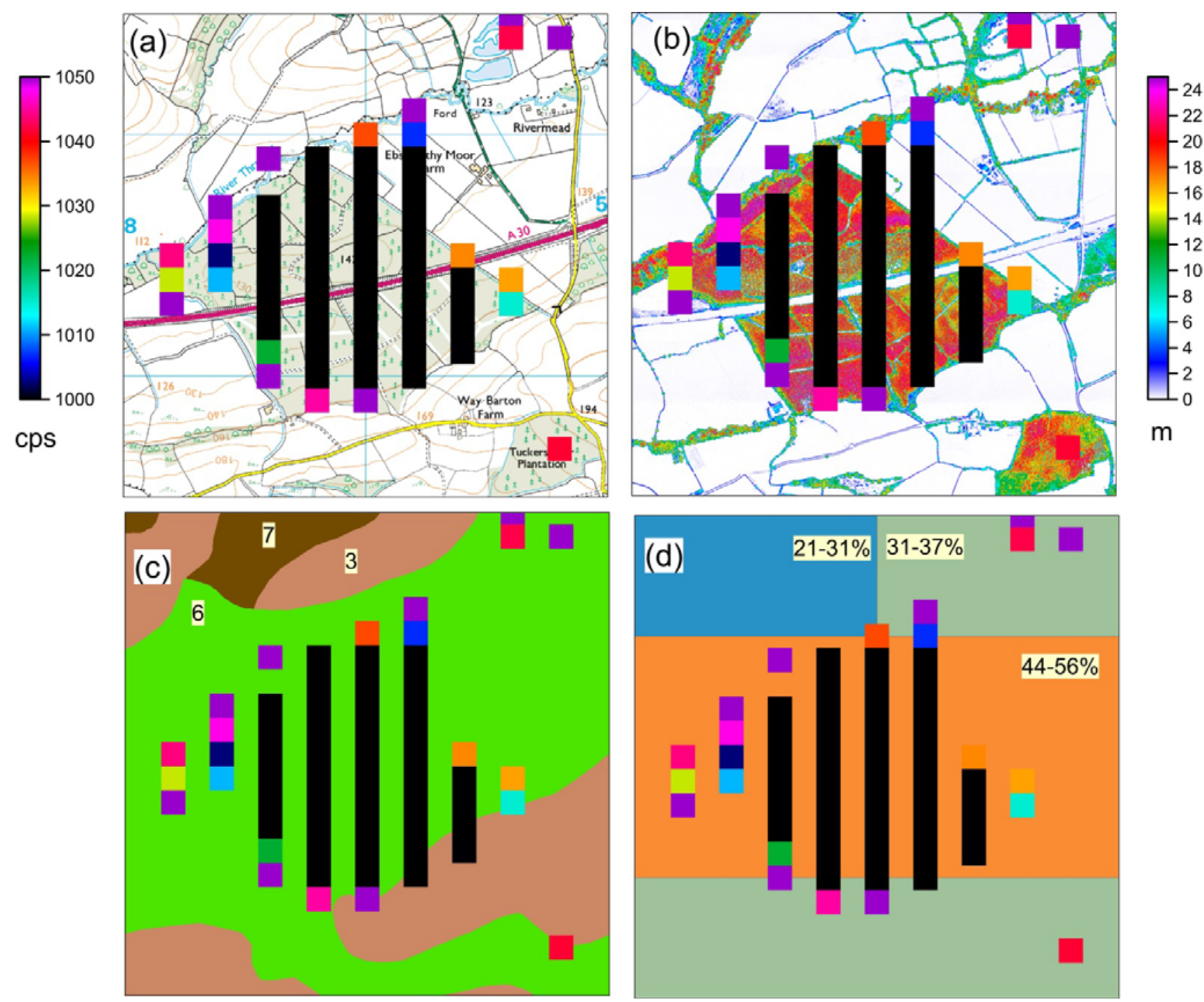